\title{
əChicago's Heat Island and Climate Change: Bridging the Scales via Dynamical Downscaling
}

\author{
Patrick Conry, ${ }^{*}$ Ashish Sharma, ${ }^{+}$Mark J. Potosnak, ${ }^{*}$ Laura S. LeO, ${ }^{*}$ Edward Bensman, ${ }^{*}$ \\ JESSICA J. HELLMANN, ${ }^{@}$ AND HARINDRA J. S. FERNANDO* \\ * Department of Civil and Environmental Engineering and Earth Sciences, University of Notre Dame, Notre Dame, Indiana \\ ${ }^{+}$Environmental Change Initiative, University of Notre Dame, Notre Dame, Indiana \\ \# Department of Environmental Science and Studies, DePaul University, Chicago, Illinois \\ ${ }^{\circledR}$ Department of Biological Sciences, University of Notre Dame, Notre Dame, Indiana
}

(Manuscript received 17 September 2014, in final form 23 February 2015)

\begin{abstract}
The interaction of global climate change and urban heat islands (UHI) is expected to have far-reaching impacts on the sustainability of the world's rapidly growing urban population centers. Given that a wide range of spatiotemporal scales contributed by meteorological forcing and complex surface heterogeneity complicates UHI, a multimodel nested approach is used in this paper to study climate-change impacts on the Chicago, Illinois, UHI, covering a range of relevant scales. One-way dynamical downscaling is used with a model chain consisting of global climate (Community Atmosphere Model), regional climate (Weather Research and Forecasting Model), and microscale ("ENVI-met") models. Nested mesoscale and microscale models are evaluated against the present-day observations (including a dedicated urban miniature field study), and the results favorably demonstrate the fidelity of the downscaling techniques that were used. A simple buildingenergy model is developed and used in conjunction with microscale-model output to calculate future energy demands for a building, and a substantial increase (as much as $26 \%$ during daytime) is noted for future $(\sim 2080)$ climate. Although winds and lake-breeze circulation for future climate are favorable for reducing energy usage by $7 \%$, the benefits are outweighed by such factors as exacerbated UHI and air temperature. An adverse change in human-comfort indicators is also noted in the future climate, with $92 \%$ of the population experiencing thermal discomfort. The model chain that was used has general applicability for evaluating climate-change impacts on city centers and, hence, for urban-sustainability studies.
\end{abstract}

\section{Introduction}

Urbanization, defined as the expansion of built-up areas, has profound meteorological and climatological implications, in addition to far-reaching socioeconomic impacts. The local response of urban areas to changing background environmental conditions (e.g., global change) is more pronounced than that of rural areas (Oleson et al. 2010). This cofunctioning of urban metabolism (the flow of heat, energy, and materials through the city; Kennedy et al. 2011) and the global climate system has received only

\footnotetext{
๖ Denotes Open Access content.
}

Corresponding author address: Patrick Conry, Dept. of Civil and Environmental Engineering and Earth Sciences, University of Notre Dame, 156 Fitzpatrick Hall of Engineering, Notre Dame, IN 46556.

E-mail: pconry@nd.edu limited attention, because pertinent studies require modeling across and observations over a multitude of scales. This challenge currently can be addressed by only a few research groups, although it is of great interest to key stakeholders in urban design and sustainability (Oke 2006). The advent of community models and comprehensive environmental databases has facilitated collaborative research into global-urban interactions, which is the genre of study that is reported upon in this paper. Such studies are opportune, considering the rapid expansion of the urban population, which now accounts for more than one-half of the world population (Ching 2013).

Urban areas are thermodynamic hotspots on the earth, given the anthropogenic heat $(\mathrm{AH})$ emissions, high heat (storage) capacity of engineered construction material, low surface albedo, heat trapping in building canyons, local buildup of greenhouse gas (GHG) pollution, and scarce vegetation for cooling by evapotranspiration 
(see appendix A for a list of acronyms used in this paper). The thermal and mechanical attributes of urban canopies lead to a range of phenomena. On the mesoscale, these include the urban heat island [UHI, or warm urban core relative to rural surroundings, especially at night; Oke (1978); Fernando et al. (2010)], distorted synoptic and mesoscale (slope and valley, sea and lake breeze) winds (Keeler and Kristovich 2012), and rainfall modification (Niyogi et al. 2011). On the microscale, urban cover is characterized by strong land-use inhomogeneities, high surface and thermal roughness, intense turbulence, anomalous dispersion/trapping of contaminants, and hydrologic modifications (e.g., impervious surfaces).

While mesoscale prediction is the basis of ambient air-quality regulations and weather prediction, it is the submeso- and microscales that undergird sustainable urban development. Issues related to these more local scales include UHI mitigation (Emmanuel and Fernando 2007), green-space impacts (Chen and Wong 2006), air pollution ( $\mathrm{Li}$ et al. 2007), pedestrian/human comfort (Müller et al. 2014; Hedquist and Brazel 2014), water usage (Guhathakurta and Gober 2010), building power loading (Salamanca et al. 2010), and emergency response (Fernando et al. 2010, Dallman et al. 2013). The microclimatic variability over a city block determines the local flow and thermodynamics that over a building determine the energy loading (Bouyer et al. 2011) and that over street canyons sway the turbulence and dispersion (Zajic et al. 2014). In general, microscales interact with and are modified by larger scales (Dimitrova et al. 2009), and the complex interactions influence the microclimatic variability of urban areas (Fernando et al. 2012; Stone et al. 2012). Sound downscaling-deriving information on smaller scales on the basis of larger scales (Leung et al. 2006) - from climate to microscales is therefore necessary and is the subject of this paper. Upscaling of information from urban to climate scales is a related research topic. It has received less attention, however, because the IPCC's Fourth Assessment Report estimates that the urban contribution to global climate variability is overshadowed by GHG emissions (Solomon et al. 2007) given that only $2 \%-3 \%$ of the earth's surface is urban. Notwithstanding, UHI and urban-warming phenomena can have significant regional impacts (Georgescu et al. 2014), although this paper is limited in scope to climate impacts on the greater Chicago, Illinois, metropolitan area (CMA).

A repertoire of available numerical models is used in this study to compute UHI and microscale inhomogeneities in CMA and to estimate the climatechange impacts on the cityscape. It was motivated by the Chicago Climate Action Plan of the city government of
Chicago that calls for aggressive action on climatechange mitigation and adaptation (Coffee et al. 2010). On the local scale, Chicago's lake breeze may have a number of impacts on future climate (Smith and Roebber 2011) that require multiscale modeling to quantify properly. Global climate model (GCM) output from the atmospheric component of the Community Climate System Model [the Community Atmosphere Model (CAM)] is input to the mesoscale Weather Research and Forecasting (WRF) Model that uses a sophisticated urban canopy parameterization (UCP) scheme to represent near-surface processes. The WRF output is then coupled with the "ENVI-met" (http:// www.model.envi-met.com/hg2e/doku.php?id=root:start) micrometeorological model running at high resolution for a test-case Chicago neighborhood, which, in turn, is coupled with a submodel for evaluation of pedestrian comfort. Because ENVI-met does not include a full treatment of building energetics, a simple heat-transfer model is developed to project UHI-induced cooling loads for a building. The questions to be addressed in this paper are 1) Can the coupling of mesoscale and microscale models, specifically WRF and ENVI-met, be implemented for climate-change applications? 2) How can global climate change affect UHI and the lake breeze in Chicago? 3) What is the impact of global and regional change at the microscales, especially in regard to pedestrian comfort and building energy consumption?

The paper is arranged as follows. Section 2 provides an overview of some common urban modeling techniques and introduces the WRF and ENVI-met models. Section 3 describes the model details and downscaling procedure particular to our study as well as submodels used for microscale applications. Section 4 provides validations of WRF, ENVI-met, and the coupling of these models. Section 5 covers the impacts of climate change on Chicago at the relevant urban and microscales. Section 6 concludes the paper with a discussion on the merits and limitations of our approach and the model chain used.

\section{Modeling of urban scales}

Regional climate models ( $\mathrm{RCM}$ ) provide atmospheric conditions at mesoscale resolution $(\sim 0.5-50 \mathrm{~km})$ for meteorological and air-quality applications, and, to improve their performance for urbanized regions, UCPs have been developed to better represent heterogeneity at the subgrid scales (Taha 1999; Lemonsu and Masson 2002; Chen et al. 2011; Park et al. 2014). Available UCPs vary in sophistication from simple bulk urban parameterizations (Taha 1999) to single- and multilayer urban canopy models (UCM), such as the Town Energy 
Balance (Masson 2000) and Building Energy Parameterization (BEP; Martilli et al. 2002) schemes. For Chicago, a city with additional complexity arising from the dominant presence of Lake Michigan, Smith and Roebber (2011) previously employed WRF coupled with a single-layer UCM (Kusaka and Kimura 2004) to study UHI.

Scales that are even smaller (e.g., urban street canyons) are handled by microscale models, which include computational fluid dynamics (CFD) models (Coirier et al. 2005; Gowardhan et al. 2011); non-CFD models with ecosystem processes such as vegetation, anthropogenic effects, and solar forcing (Matzarakis et al. 2007; Lindberg et al. 2008); and hybrids of the above approaches (Bruse and Fleer 1998; Ma et al. 2012). Specialpurpose models exist, for example, to account for the energy balance of individual buildings (Crawley et al. 2008) and human comfort indoors (Fangers 1970; Mayer and Höppe 1987) and outdoors (Jendritzky 1990).

Information flow between scales is conducted by downscaling and upscaling (Wang et al. 2004; Chen et al. 2012), with downscaling being computationally feasible for us at present. Two types of downscaling exist: statistical and dynamical. Statistical downscaling has been widely employed to link climate change and UHI for several cities (Wilby 2003; Rosenzweig et al. 2005; Thorsson et al. 2011), including Chicago (Hayhoe et al. 2010). These techniques, nevertheless, have limitations: 1) being based on correlations developed by using past observations, they do not account for emergent properties, 2) future conditions may exceed previously recorded extremes, thus creating a void of data for correlations, and 3) climateregime shifts cannot be captured. Dynamical downscaling, on the other hand, connects future climate with UHI through numerical modeling and has less reliance on past data.

Previous studies have downscaled GCM outputs for the future by using RCMs and UCMs to achieve $3-\mathrm{km}$ (Kusaka et al. 2012) and 1-km (Hamdi et al. 2013; Lemonsu et al. 2013) horizontal resolutions. UHI studies have used submodels in conjunction with RCMs, some recent examples being evaluations of pedestrian heat-disorder risk (Ohashi et al. 2014), energy consumption (Gutiérrez et al. 2013), and surface exchanges of heat and moisture ( $\mathrm{Li}$ and Bou-Zeid 2013). Mesoscale-model output has been fed into CFD models (Fernando et al. 2001; Brown et al. 2001; Baik et al. 2009) to study the microscale response to mesoscale variability.

Thus far, GCM output has not been downscaled to the finest microscales $(0.5-10 \mathrm{~m})$ using CFD models through multimodel nesting. Früh et al. (2011) came close by using a "dynamical-statistical" downscaling approach and interpolating output from a microscale urbanclimate model in offline mode to predict UHI effects at 50-m resolution. As mentioned, in this paper we use a model chain that consists of CAM, WRF, and ENVImet. WRF has been successful in capturing urban heterogeneity (Chen et al. 2011) and sea breeze (Lin et al. 2008; Salamanca et al. 2011) and has handled the effects of Lake Michigan in Chicago's context (Smith and Roebber 2011). Among the array of parameterization schemes available, a complex UCP that couples BEP and the Building Energy Model (BEM; Salamanca et al. 2010) schemes (BEP + BEM) was utilized, although simpler schemes may also work equally well for certain applications (Grimmond et al. 2011). This scheme has superior ability to treat partial $\mathrm{AH}$ effects that have been shown to influence UHI (Salamanca et al. 2012) and may become even more important in future climate.

The ENVI-met model, version 3.1 (Bruse and Fleer 1998), was selected because it does not overly parameterize most components of urban microclimate. It combines a Reynolds-averaged Navier-Stokes atmospheric model, which employs the Boussinesq approximation and a $k-\varepsilon 1.5$-order turbulence closure scheme, with explicit treatment of radiative fluxes, vegetation, and soil. It has been used for studies on air quality (Vos et al. 2013), pedestrian thermal comfort (Ali-Toudert and Mayer 2006), and UHI mitigation (Emmanuel and Fernando 2007; Chow and Brazel 2012; Müller et al. 2014), often with urban-planning relevance (Chen and Wong 2006; Ali-Toudert and Mayer 2006; Vos et al. 2013), but prohibitive computational cost prevents its use for real-time forecasting. ENVI-met is available online as freeware (http://www.envi-met.com).

\section{Model setup}

\section{a. Mesoscale model}

For present climate, WRF dynamically downscales North American Regional Reanalysis (NARR) output at $32-\mathrm{km}$ resolution to $0.333 \mathrm{~km}$; it moves across the spatial scales using a nesting approach $(32>9>3>$ $1>0.333 \mathrm{~km}$ ) shown in Figs. 1a-c. The number of vertical levels is 50 , and the planetary boundary layer parameterization is the Mellor-Yamada-Janjić scheme (Janjić 1994). For future climate, CAM output at $2.5^{\circ} \times 2.5^{\circ}\left(2.5^{\circ} \approx 200 \mathrm{~km}\right)$ is fed into WRF and is dynamically downscaled to $0.333 \mathrm{~km}$ through nesting $\left(2.5^{\circ}>32 \mathrm{~km}>9 \mathrm{~km}>3 \mathrm{~km}>1 \mathrm{~km}>0.333 \mathrm{~km}\right)$. Prior to being fed into WRF, CAM outputs obtained with the Hadley Centre SST dataset for the "representative 

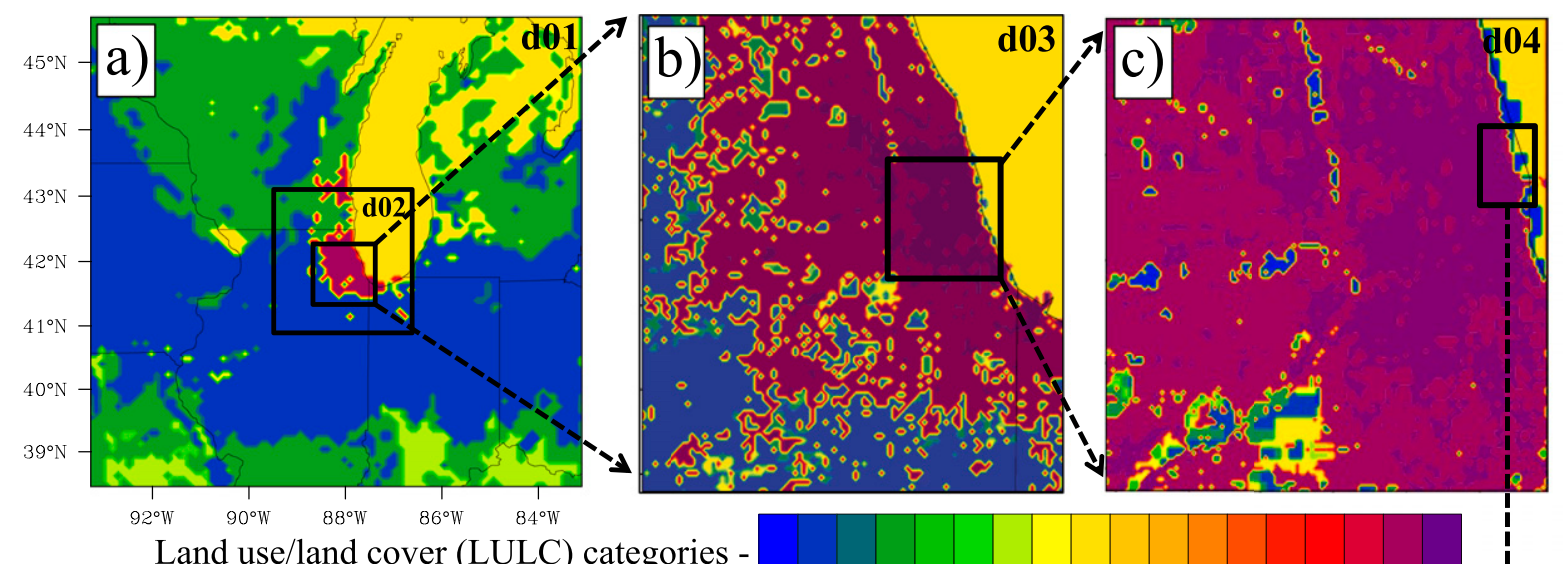

Land use/land cover (LULC) categories -

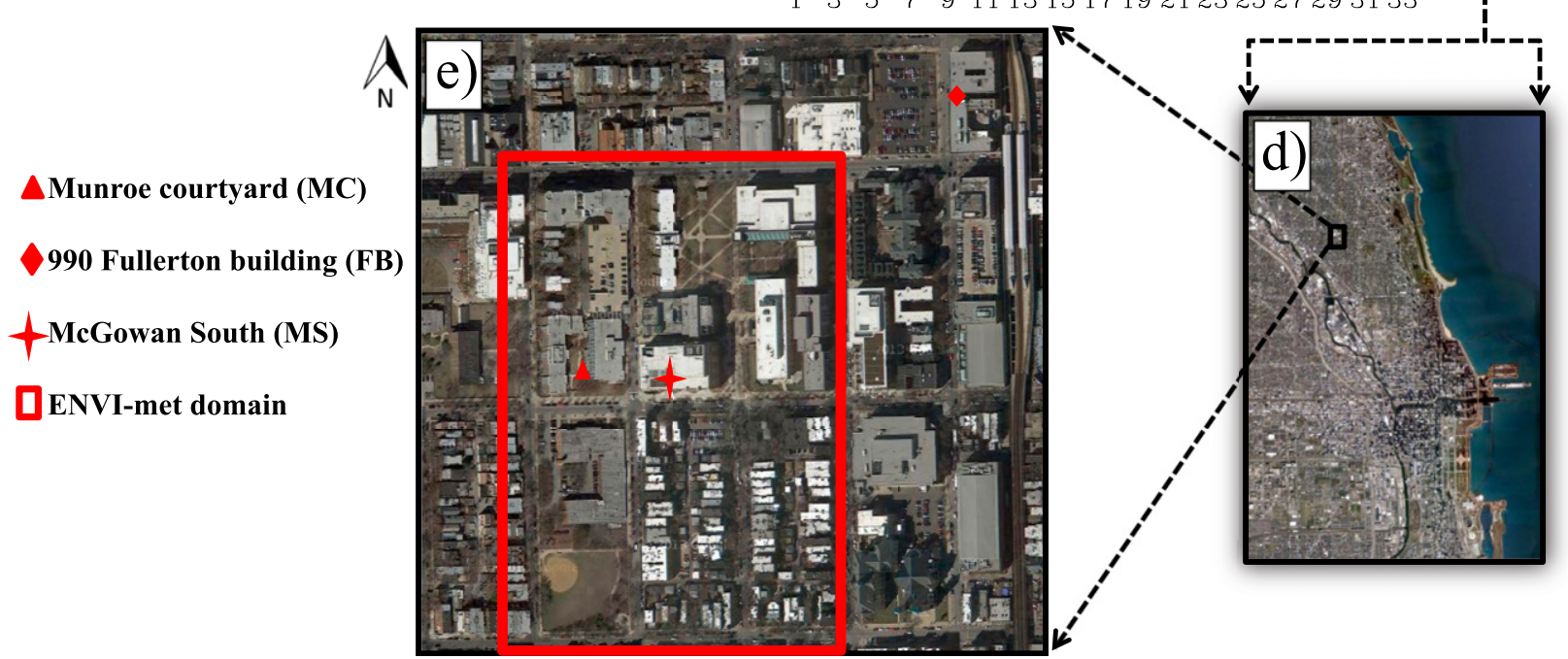

FIG. 1. Dynamical downscaling for the Chicago area at different spatial resolutions (cf. Conry et al. 2014a). (a) WRF domain with nested grid sizes of $9>3>1>0.333 \mathrm{~km}$ for regional climate modeling. We use the NARR 32-km dataset to feed outermost domain 1 (d01) with boundary and initial conditions. Domains d01 and d02 have resolutions of 9 and $3 \mathrm{~km}$, respectively. Colors represent U.S. Geological Survey LULC categories as defined on the scale. (b) LULC for the CMA for d03 at 1-km resolution. (c) The innermost domain (d04) at $0.333-\mathrm{km}$ resolution that is coupled with ENVI-met. LULC categories 31, 32, and 33 correspond to low-, medium-, and high-intensity urban land use, respectively, for (b) and (c). The rural area surrounding the city is predominantly cropland (LULC 3). (d) The extensive urbanized region surrounding the city of Chicago (copyright Google). (e) Telescopic view of ENVI-met microscale domain. Observational locations used in the July and August 2013 field experiment are shown, as defined in the legend. The orientation indicated by the north arrow shown here applies to all subsequent figures.

concentration pathway" of $8.5 \mathrm{~W} \mathrm{~m}^{-2}$ (RCP8.5) were averaged over the years 2076-81. Although the use of a single scenario rather than an ensemble approach introduces uncertainty, the choice of the worst-case scenario was motivated by the goal of displaying extreme changes that can be averted by global and cityscale mitigation and adaptation strategies. As mentioned, the BEP + BEM scheme was used, herein called WRF-urban, which, in our case, was fine-tuned on the basis of sensitivity studies for CMA (Sharma et al. 2014). For land use/land cover (LULC) for present and future, WRF-urban utilized the $2006 \mathrm{Na}-$ tional Land Cover Database (NLCD) for urban areas and the U.S. Geological Survey's 24 land-use and 16 soil categories elsewhere.

\section{b. Microscale model}

A 3D model was created with 2-m fine horizontal resolution, with a domain that is located at $41.9239^{\circ} \mathrm{N}$, $87.7128^{\circ} \mathrm{W}$ within a Lincoln Park neighborhood in Chicago (Figs. 1d,e). It comprises the western portion of the DePaul University campus to the north and small, densely packed residential buildings to the south. This area has a variety of building sizes and land cover types, including a park in the southwest corner. The domain size is $370 \times 438 \mathrm{~m}^{2}$, with nesting grids beyond this to 
ensure proper boundaries, as recommended for urban CFD models (Franke et al. 2007). The vertical grid resolution was also $2 \mathrm{~m}$ up to the maximum building height $(32 \mathrm{~m})$, above which grid cells were telescoped for a total vertical height of $162 \mathrm{~m}$, which was estimated as the maximum characteristic extent for the roughness sublayer. Building dimensions and land cover classification were determined using a building-footprint data file from the "City of Chicago Data Portal" (https://data.cityofchicago. org/) as well as satellite and street-level imagery. For vegetation and soil types, ENVI-met's default databases, which govern exchanges of heat and moisture with the atmosphere as well as plant shape and leaf area density, were appropriate to use because they are for a temperate climatic zone like Chicago.

The lateral and upper boundary conditions for 3D ENVI-met are supplied by a 1D atmospheric model overlying the $3 \mathrm{D}$ domain, which extends from the surface up to $2500-\mathrm{m}$ elevation. Initial conditions for this 1D model are input by the user, and thereafter the model marches forward without further forcing past this initialization. Previous studies have used meteorological observations for initialization (Emmanuel and Fernando 2007; Chow and Brazel 2012; Müller et al. 2014). The model most effectively simulates 24 48-h periods of relatively steady regional atmospheric circulation when initialized at the approximate time of sunrise. All previous ENVI-met studies have necessarily made the assumption of steady conditions, but only rarely have they delved into or verified this assumption (Maggiotto et al. 2014). We undertook careful analysis and validation to investigate this assumption (section 4), whereupon the model could be used with confidence for climate-change applications for which changes in average conditions are of greatest interest and individual mesoscale events requiring nonsteady input (such as weather forecasting) are of lesser concern.

Certain ENVI-met parameters were adjusted to better represent the area being modeled. We modified the roughness height to $0.5 \mathrm{~m}$ (Grimmond et al. 1998; Chow et al. 2011; Maggiotto et al. 2014). The overall heat transfer coefficients ( $U$ values) for all building walls and roofs were respectively set to 0.2 and $0.5 \mathrm{~W} \mathrm{~m}^{-2} \mathrm{~K}^{-1}$, following Frank (2005). For soil parameterizations, default soil moisture content and surface temperature of $50 \%$ and $20^{\circ} \mathrm{C}$, respectively, were used, but soil was set to have a decreasing temperature gradient with lower-layer temperatures of $19^{\circ}$ and $18^{\circ} \mathrm{C}$. All simulations began at 0600 Chicago local standard time (LST) and lasted $48 \mathrm{~h}$, utilizing $1 \mathrm{~h}$ of spinup time. On our computing system, $1 \mathrm{~h}$ of simulation time took, on average, $4 \mathrm{~h} 10 \mathrm{~min}$ of real time because of the high computational cost associated with ENVI-met's extensive treatment of microclimatic processes.

\section{c. Coupling the models}

WRF-urban model output at $0.333-\mathrm{km}$ resolutionon the same scale as the ENVI-met domain size-was fed (offline) into ENVI-met to initialize simulations. The WRF-urban vertical grid cell was collocated with the ENVI-met domain so that it covers the same area of the atmosphere that is occupied by the overlying 1D ENVImet model. Previous ENVI-met studies have utilized observations to provide initial conditions, and thus our coupling approach is a new application for ENVI-met. WRF-initialized simulation is later compared with that initialized by observations to investigate the efficacy of our approach (section 4). WRF-urban output provided some information that is not typically available from urban meteorological observations: 1) area-representative surface meteorological conditions, free from potential biases caused by instrument location, 2) temperature of the soil upper layers, and 3) relative soil moisture level, accounting for events of previous days (e.g., rain). ENVImet initial conditions were also adjusted according to this information in the future simulations that are discussed in section 5. For both present and future Augusts, WRF showed drier soil than ENVI-met's default moisture content $(50 \%)$, and therefore it was reduced to $25 \%$.

\section{d. Pedestrian-comfort submodel}

Thermal comfort is an important aspect of urban microclimate because it dictates quality of life of city dwellers-for example, time spent outdoors, social and economic behavior, morbidity and mortality, and workplace productivity (Harlan et al. 2006). An available submodel of ENVI-met was employed to facilitate thermal-comfort calculation; Predicted Mean Vote (PMV; Fangers 1970), one of the earliest developed indoor thermal-comfort models, has been more recently applied to outdoor environments (Jendritzky 1990). It calculates an index of thermal comfort on a scale typically ranging from -4 (very cold) to +4 (very hot) and has been statistically correlated with the "predicted percentage dissatisfied" (PPD) to determine the fraction of a population that will experience thermal discomfort in a given environment. Although a previous field study by Thorsson et al. (2004) revealed biases in PMV index as compared with self-reported thermal sensations, PMV remains one of the most reasonable thermal comfort indices to have been coupled with ENVI-met (Hedquist and Brazel 2014). Also, note that for the Thorsson et al. (2004) field study the model's steady-state assumption did not apply. The coupled calculations utilize environmental factors (air temperature $T_{a}$, mean radiant temperature $T_{\mathrm{mrt}}$, relative humidity, and wind speed) directly from ENVI-met output and must assume human-specific 
model parameters. Our choice was a young man walking at a speed of $1 \mathrm{~m} \mathrm{~s}^{-1}$ and wearing light summer clothes so that the mechanical factor and energy exchange are 0.25 and $120 \mathrm{~W} \mathrm{~m}^{-2}$, respectively (Mian et al. 2006).

\section{e. Building-energy submodel}

ENVI-met's treatment of buildings is incomplete in that it does not allow for direct evaluation of energy usage. To this end, we have developed a simple buildingenergy submodel to estimate the microclimatic contributions to building cooling loads (cf. Conry et al. 2014a). This submodel only accounts for the influence of external environmental factors (radiative fluxes, temperature, and winds). Alternate, more sophisticated building-energy models (DOE 2013; Bouyer et al. 2011; Salamanca et al. 2010) consider additional effects, such as windows, HVAC system, and heat generation inside by people and equipment. Our goal, however, is to separate the influence of urban microclimate, which will likely be affected by background climate change in the next several decades, from other variables that could change significantly in the coming years as a result of, for example, technological advancements in HVAC systems and building designs.

Our building-energy model assumes that all heat transfer occurs at a pair of nodes (one interior and the other exterior) for each of the building's six insulating elements (four walls, roof, and base). In the following equations, subscript $i$ denotes variables that differ for each insulating element. The symbols $T$ and $\tau$ represent exterior and interior temperatures, respectively. Assuming no infiltration or exfiltration of air (ventilation), no heat exchange between interior zones, and a quasisteady state, the power output from an air-conditioning system $Q^{\text {sys }}$ required for constant (well mixed) interior room temperature $\tau^{r}$ (set to $20^{\circ} \mathrm{C}$ ) is given by

$$
-Q^{\mathrm{sys}}=\sum_{i=1}^{N_{\text {surfaces }}} h^{c} A_{i}\left(\tau_{i}^{s}-\tau_{i}^{r}\right),
$$

in which the convective-heat-flux term at each interior surface is used as it controls heat transfer from a wall to interior air [see Eq. (2), below]. Details on all variables are given in appendix B. The convective-heat-transfer coefficient $h^{c}$ for the interior is taken as $8 \mathrm{Wm}^{-2} \mathrm{~K}^{-1}$ (Salamanca et al. 2010). The unknown interior surface temperatures $\tau_{i}^{s}$ must be found by setting up the heatbalance equation at each interior surface, approximated as

$$
\left(k_{i} / L_{i}\right)\left(T_{i}^{s}-\tau_{i}^{s}\right)=h^{c}\left(\tau_{i}^{s}-\tau^{r}\right),
$$

in which the conductive heat flux balances the convective heat flux. For overall heat-transfer coefficients
( $U$ values), given by $k_{i} / L_{i}$, values of $0.2,0.5$, and $0.8 \mathrm{~W} \mathrm{~m}^{-2} \mathrm{~K}^{-1}$ are used for the walls, roof, and base, respectively (Frank 2005). The exterior surface temperatures $T_{i}^{s}$ are found by using

$$
\begin{gathered}
\left(1-\alpha_{i}\right) q_{i}^{\mathrm{sw}}+q_{i}^{\mathrm{lw}}+h_{i}^{c}\left(T_{i}^{a}-T_{i}^{s}\right) \\
\quad=\varepsilon \sigma\left(T_{i}^{s}\right)^{4}+\left(k_{i} / L_{i}\right)\left(T_{i}^{s}-\tau_{i}^{s}\right),
\end{gathered}
$$

in which, on the left-hand side, the three terms represent the incident shortwave radiative flux, longwave radiative flux, and convective heat flux, respectively. The right-hand side has two terms representing longwave radiation emission and conductive heat flux toward the interior. On the exterior, the convective-heat-transfer coefficient $h_{i}^{c}$ is influenced by the wind speed $V_{i}$ and the incident angle of the wind $\beta_{i}$. For walls, this relationship was calculated on the basis of regression equations that were presented in Liu and Harris (2007) for all possible wind incidence angles. The work of Emmel et al. (2007) was used for the equations for rooftop convective-heattransfer coefficient.

The system of equations given in Eqs. (1)-(3) is nonlinear because of the longwave-radiation-emission term $\varepsilon \sigma\left(\mathrm{T}_{i}^{s}\right)^{4}$ in Eq. (3), and therefore for computational convenience the term was linearized using $T_{i}^{s}$ from the previous time step as in Manfred and Schmidt (2008). For the first time step, the wall temperature output from the ENVI-met simulation was used, but it was not used thereafter because ENVI-met's treatment of building energy is less robust. The linearized mathematical system can be solved numerically to find the 12 unknown surface temperatures and $Q^{\text {sys }}$. All other variables are provided by ENVI-met or are assumed on the basis of previous work. Radiative fluxes $q_{i}^{\mathrm{sw}}$ and $q_{i}^{\mathrm{lw}}$ from ENVImet output were spatially averaged over the entire building surface, whereas $V_{i}, \beta_{i}$ (Liu and Harris 2007), and $T_{i}^{a}$ were taken at the centroid of the surface. Emissivity $\varepsilon$ was assumed to be 0.7 for brick, and ENVImet default albedo values $\alpha_{i}(0.2$ for walls and 0.3 for roofs) were assumed. The exterior surface temperature of the building's base element was approximated as the temperature of the lowest ENVI-met soil layer, eliminating the need to apply Eq. (3) for the floor.

The assumptions made above do impose some limitations on the applicability of the model that was developed. For instance, during the evening transition, Eq. (3) changes significantly, with the shortwave radiation term, which is dominant during the daytime, quickly approaching zero and the linearized longwave radiation emission term becoming dominant. The linearization therefore becomes problematic during nighttime, and, as a result of this and the potential inapplicability of the 
TABLE 1. Location and LULC for meteorological stations used for WRF-urban validation as well as calculated performance statistics for temperature (temp) and wind speed (ws).

\begin{tabular}{|c|c|c|c|c|c|c|}
\hline \multirow[b]{2}{*}{ Station identifier* } & \multirow[b]{2}{*}{ Lat, lon $\left({ }^{\circ} \mathrm{N},{ }^{\circ} \mathrm{W}\right)$} & \multirow[b]{2}{*}{ LULC $* *$} & \multicolumn{2}{|c|}{ 2-m temp $\left({ }^{\circ} \mathrm{C}\right)$} & \multicolumn{2}{|c|}{ 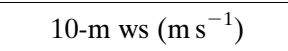 } \\
\hline & & & RMSE & MAE & RMSE & MAE \\
\hline MDW & $41.7841,87.7551$ & LI & 1.27 & 1.04 & 1.38 & 1.16 \\
\hline ORD & $41.9875,87.9319$ & LI & 1.78 & 1.45 & 1.22 & 0.99 \\
\hline AR820 & $41.9600,87.7995$ & MI & 2.34 & 2.00 & 1.22 & 1.03 \\
\hline D6362 & $41.9483,87.6586$ & $\mathrm{HI}$ & 1.36 & 1.06 & 1.33 & 1.05 \\
\hline D7813 & $41.8238,87.8485$ & LI & 2.46 & 2.06 & 1.06 & 0.85 \\
\hline D8777 & $41.9333,87.6725$ & $\mathrm{HI}$ & 1.25 & 1.02 & 1.53 & 1.07 \\
\hline E3114 & $41.8818,87.6633$ & $\mathrm{HI}$ & 1.41 & 1.09 & 1.19 & 0.90 \\
\hline IL010 & $41.8325,87.6949$ & $\mathrm{HI}$ & 1.53 & 1.21 & 1.57 & 0.85 \\
\hline
\end{tabular}

* First two stations are NWS meteorological stations at O'Hare and Midway airports; the others were accessed online (http://mesowest. utah.edu).

** LULC urban categories are based on the 2006 NLCD: low, medium, and high intensity are indicated by LI, MI, and HI.

quasi-steady-state assumption during evening transition, the results outside the daytime convection period should be viewed with circumspection. Therefore, later results for daytime only are presented, capturing the period of peak energy demand.

\section{Model validation}

\section{a. WRF validation}

Eight Chicago meteorological stations located in different LULC classification areas were selected to test the sensitivity of WRF-urban output for near-surface temperature and winds (Table 1). Corresponding WRFurban grid cells provided hourly data to compare with the observed temperatures and wind speeds for the period of 15-19 August 2013 (Figs. 2 and 3), which coincided with a field experiment that provided data for ENVI-met validation. The mean absolute error (MAE) and root-mean-square error (RMSE) were used as statistical performance measures.

The comparisons for temperature in Fig. 2 and Table 1 assume that a single observational point can represent average conditions within a $0.333 \mathrm{~km} \times 0.333 \mathrm{~km}$ grid cell. High-resolution RCM simulations can capture the average surface temperature trend for a particular grid cell, but observations can be biased by local variations of LULC in the immediate vicinity of sensors, which is a known drawback of mesoscale comparisons. For example, whereas stations in exposed areas (Midway International Airport, O'Hare International Airport, and station D8777) compare exceptionally well to simulations throughout the diurnal cycle, stations in residential areas (AR820 and D7813) with proximate vegetation covering a small area generally perform well during the daytime but have a positive bias during nighttime; this can be attributed to localized cooling of vegetated areas at night. Such phenomena are more efficiently captured by microscale models. In a similar way, stations that are located very close to paved surfaces (e.g., IL010) experience amplified heating on cloud-free days that is due to the thermal characteristics of these nearby surfaces. Overall, WRF-urban performs tolerably, with only one MAE value exceeding $2^{\circ} \mathrm{C}$.

Wind speed comparisons in Fig. 3 and Table 1 show that WRF-urban has low error during both daytime and nighttime, with an average MAE of $\sim 1 \mathrm{~m} \mathrm{~s}^{-1}$. Given that Lake Michigan has a major impact on Chicago's local climate, the criteria developed by Laird et al. (2001) were employed to determine the lake-breeze influence. These criteria separate the lake breeze from the synoptic influence by requiring a change in wind conditions between morning and afternoon as well as a positive temperature gradient between lake and land. Using observations and WRF-urban output at O'Hare (ORD), Midway (MDW), and the DePaul University field-experiment location (MS; see Fig. 1e), lake-breeze occurrences were counted for five days (15-19 August) at each location. WRF-urban is able to predict these lake-breeze occurrences, as based on a contingency study (Wilks 1995), with $100 \%$ probability of detection and only one false detection, leading to a false-alarm rate of 0.07 and a $20 \%$ probability of false detection. This provides credence for using WRF-urban to study the interaction of the lake breeze with the UHI, as expected on the basis of the prior success of WRF-urban in capturing the Houston, Texas, sea breeze (Salamanca et al. 2011).

\section{b. WRF-urban and ENVI-met coupling}

A special field campaign was conducted in July and August of 2013 to obtain observational data for initialization and validation of ENVI-met, which required 

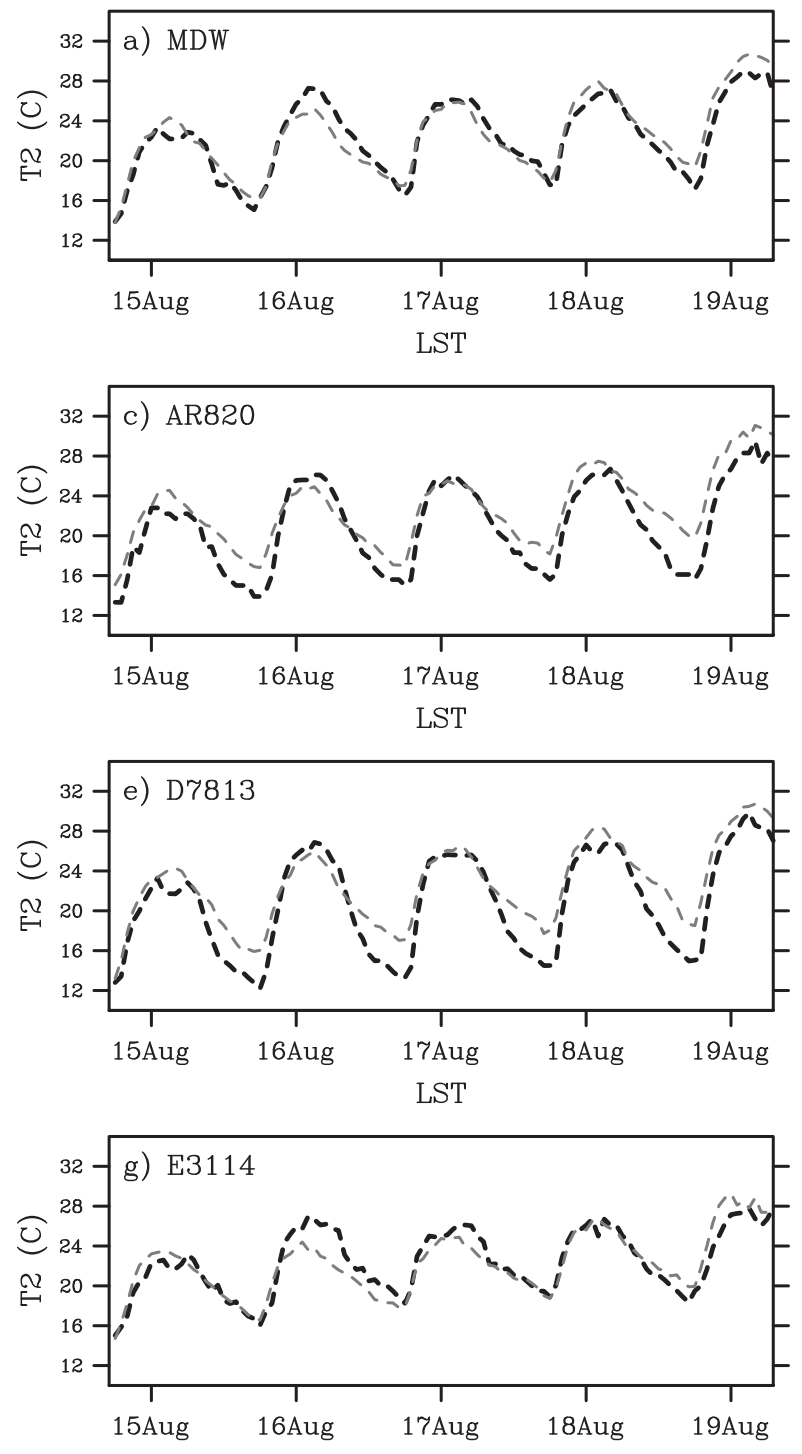

$$
\text { - - - WRF-urban }
$$

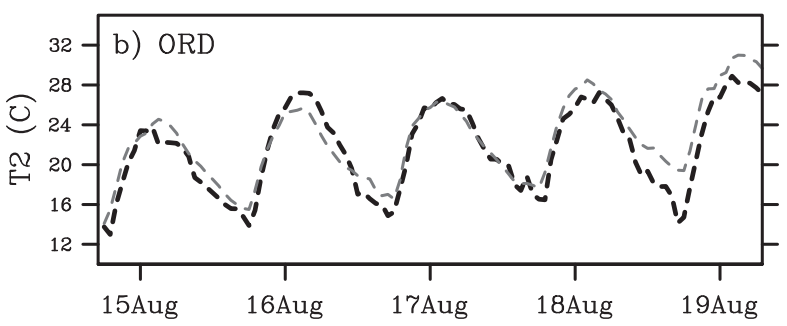

LST
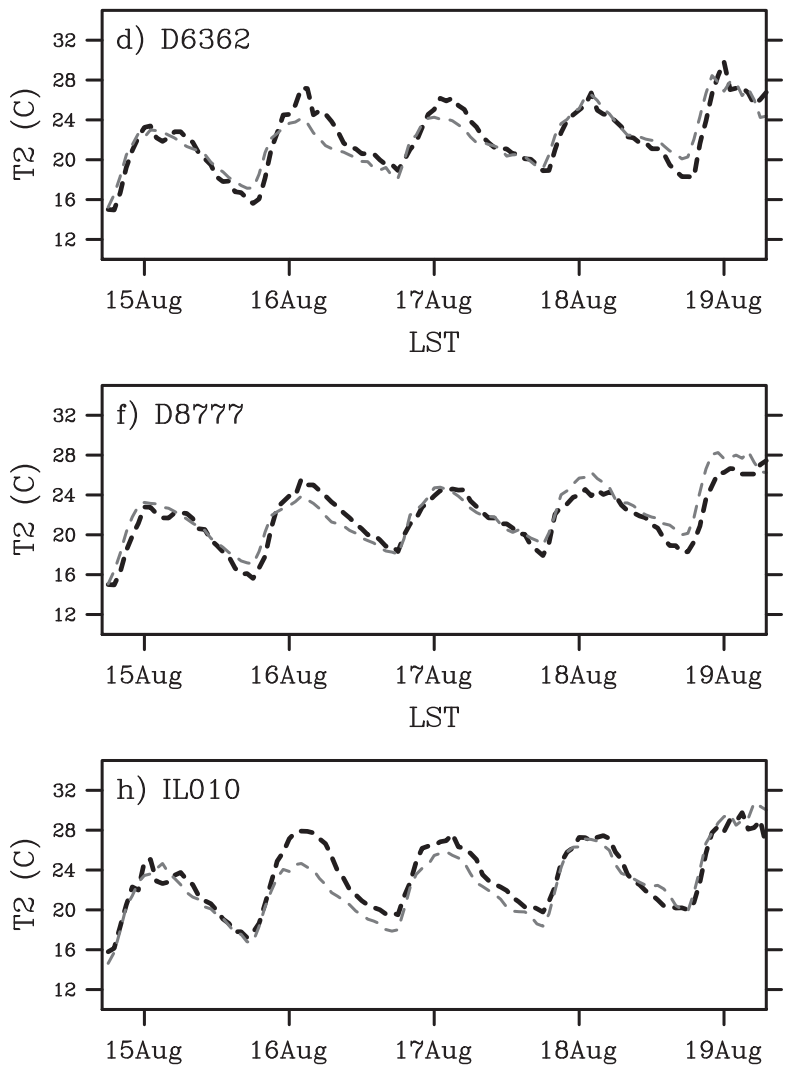

LST

FIG. 2. Comparison of 2-m surface temperatures for WRF-urban and observations for different stations with varying LULC within the CMA. The stations' positions (latitude, longitude) and LULC are shown in Table 1 along with error-measure statistics. Tick marks along the $x$ axes correspond to 1200 LST on given day.

data at high spatial resolution. Equipment was distributed on the campus of DePaul University, as displayed in Fig. 1e, and the temperature at several locations as well as the relative humidity, wind velocity, and turbulent fluxes at two rooftop locations was measured. Table 2 outlines the equipment deployed on five separate towers.

Upon scrutiny of the data, a few periods were found to approximately satisfy the requirement of steady conditions, and 17-18 August, the longest such period, was selected to be used in conjunction with ENVI-met. NCEP-NCAR reanalysis data show that a high pressure ridge settled over the Great Lakes region during this period, causing light easterly gradient winds as well as conditions favorable for an easterly lake breeze (Laird et al. 2001). Steady conditions ended at approximately midnight on 19 August because of the passage of a synoptic front. The front's passage had a profound impact on conditions at the experimental site at 0100 LST, with local modification of atmospheric stability and turbulent fluxes (Conry et al. 2014b). Thereafter, the ENVI-met performance is expected to be poor because it is driven by a steady meteorological input. 

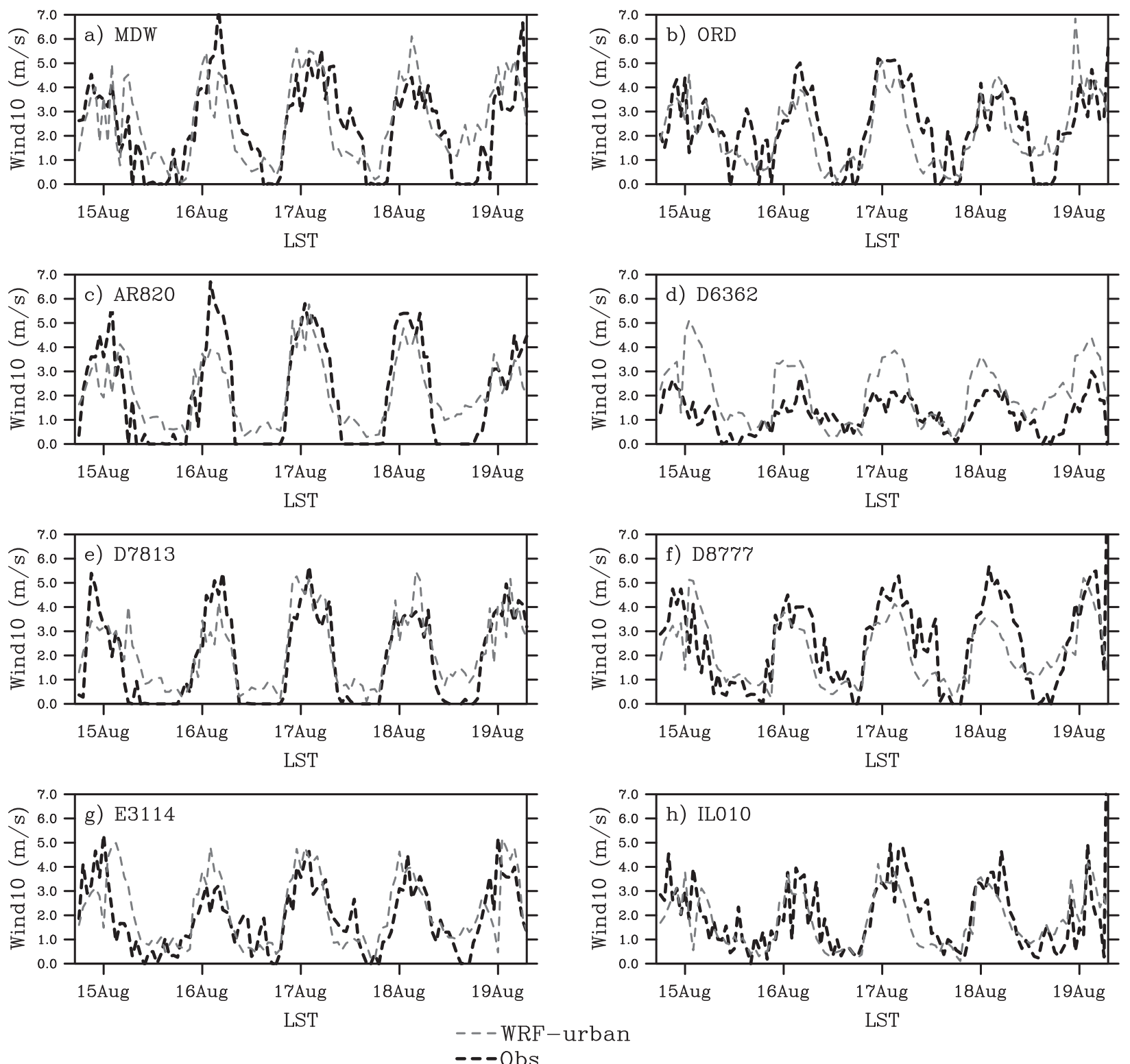

FIG. 3. As in Fig. 2, but for 10-m wind speed.

Figures $4 \mathrm{a}-\mathrm{c}$ present comparisons of observed and simulated temperatures at three locations in the microscale domain for 48-h ENVI-met simulations with observations and WRF-urban output used as two different types of initial conditions. From a visual perspective, prior to 0100 LST 19 August the coupled WRF-urbanENVI-met outperforms ENVI-met initialized by observations. To assess the model performance quantitatively, three difference measures were employed, as suggested by Willmott (1982); as before, RMSE and MAE were used, with the additional "refined index of agreement" $d_{r}$ (Willmott et al. 2012). Table 3 reports these difference measures for data displayed in
Figs. $4 \mathrm{a}-\mathrm{c}$, calculated without the data taken after the frontal passage at 0100 LST 19 August. Note that $d_{r}$ values approaching 1 indicate good model performance. All ENVI-met simulations showed comparable or superior model performance when compared with previous studies (Emmanuel and Fernando 2007; Chow et al. 2011; Chow and Brazel 2012). An important finding is that the predicted near-surface temperature is more accurate when the WRF-urban output is used to initialize ENVI-met rather than observational data. This can be explained by using the representativeness of the WRF-urban output as an "average value" for the domain, thus providing a robust initialization profile. On 
TABLE 2. Experimental setup of the field campaign conducted in July and August 2013 and description of how observations were used in this study. ARL indicates "above roof level."

\begin{tabular}{|c|c|c|c|c|}
\hline Location & Tower & Instruments & $\begin{array}{l}\text { Initialization } \\
\text { variable(s) }\end{array}$ & $\begin{array}{l}\text { Validation } \\
\text { variable }\end{array}$ \\
\hline \multirow[t]{2}{*}{$\begin{array}{l}\text { McGowan South } \\
\text { building rooftop }\end{array}$} & MS1 & $\begin{array}{l}\text { One R. M. Young Co. } 81000 \text { sonic anemometer, } \\
\text { one Campbell Scientific, Inc., HMP45C } \\
\text { temp/RH probe, and three thermocouples }\end{array}$ & 3-m ARL RH & 2-m ARL temp \\
\hline & MS2 & Two thermocouples & - & 2-m ARL temp \\
\hline \multirow[t]{2}{*}{ Munroe Courtyard } & MC1 & Two thermocouples & - & 2-m AGL temp \\
\hline & $\mathrm{MC} 2$ & One thermocouple & 2-m AGL temp & - \\
\hline $\begin{array}{l}990 \text { Fullerton building } \\
\text { rooftop }\end{array}$ & FB & $\begin{array}{l}\text { One R. M. Young } 81000 \text { sonic anemometer and } \\
\text { three thermocouples }\end{array}$ & $\begin{array}{l}\text { 5-m ARL wind } \\
\text { speed and direction }\end{array}$ & - \\
\hline
\end{tabular}

the other hand, the data obtained at an individual urban site cannot always be representative of the larger domain, given the high land cover gradients within urban areas and the scarcity of reliable urban observations. In our case, $\mathrm{MC1}$ located in a vegetated courtyard was used for initialization as the only available ground-level measurements; it showed a cool bias during nighttime as a result of localized cooling from vegetation. This is seen in Fig. 4a for the early morning of 18 August (0400 $0700 \mathrm{LST}$ ) relative to other observational locations and raw 2-m WRF temperature output. The advantage of using mesoscale output rather than observations for
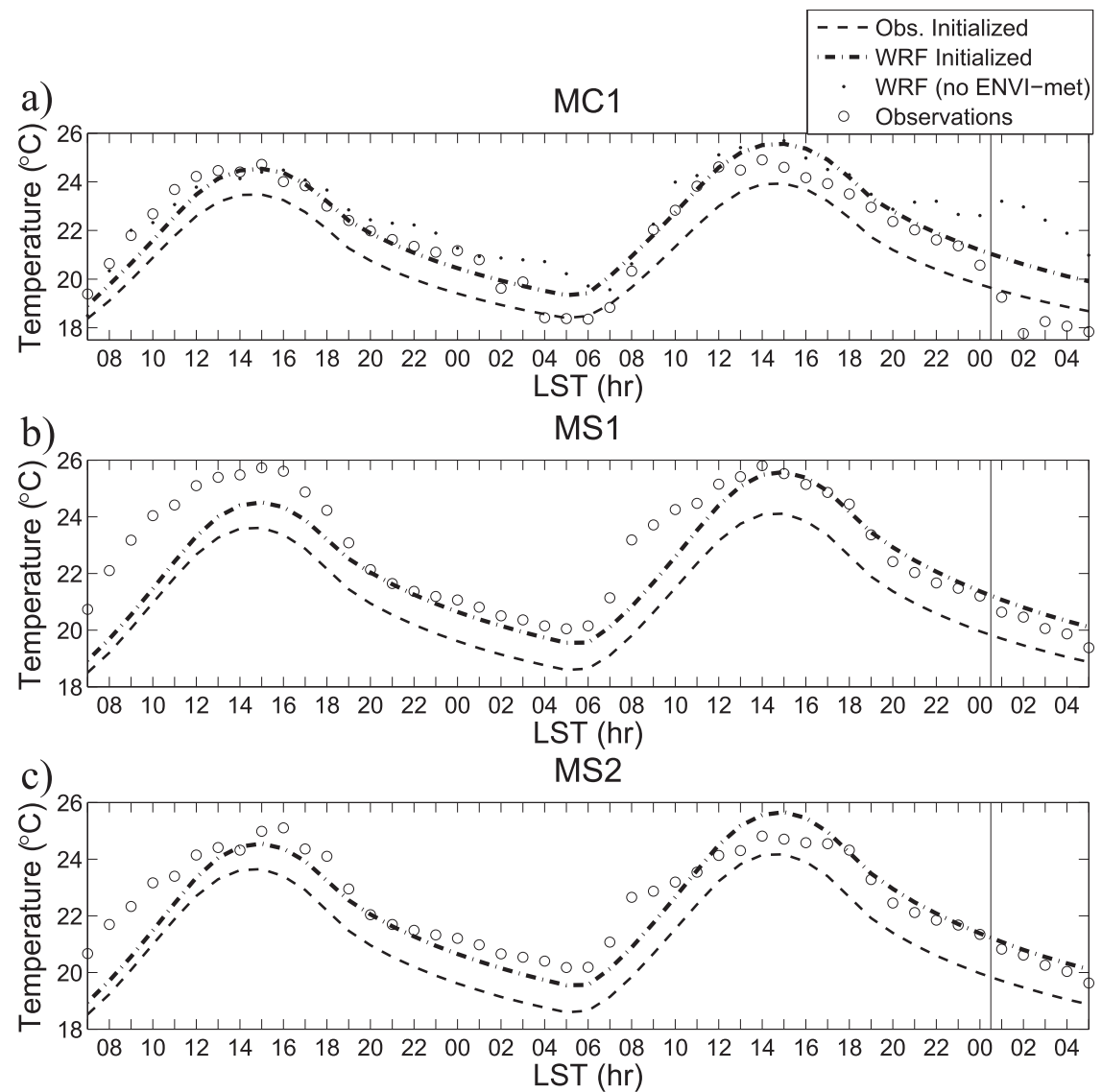

FIG. 4. ENVI-met model output vs observations. Time series comparison for 17-18 Aug 2013 for the (a) MC1, (b) MS1, and (c) MS2 towers (see Table 2 for details). WRF-urban 2-m temperature output is included in (a) as well. The vertical line indicates approximate front arrival time; data beyond this line (19 Aug) are excluded from the statistical comparisons in Table 3 . 
TABLE 3. Performance statistics for predicted temperatures vs observations at MC1, MS1, and MS2 (corresponding data can be found in Fig. 4) from ENVI-met simulations with initialization from either WRF-urban output or observations.

\begin{tabular}{lccllllll}
\hline \hline & \multicolumn{2}{c}{$\mathrm{RMSE}\left({ }^{\circ} \mathrm{C}\right)$} & & \multicolumn{2}{c}{ MAE $\left({ }^{\circ} \mathrm{C}\right)$} & & \multicolumn{2}{c}{$d_{r}$} \\
\cline { 2 - 3 } \cline { 8 - 9 } \cline { 8 - 9 } & WRF & Obs & & WRF & Obs & & WRF & Obs \\
\hline MC1 & 0.65 & 1.21 & & 0.53 & 0.99 & & 0.839 & 0.658 \\
MS1 & 1.15 & 1.94 & & 0.86 & 1.84 & & 0.748 & 0.464 \\
MS2 & 0.82 & 1.54 & & 0.65 & 1.30 & & 0.760 & 0.461 \\
\hline
\end{tabular}

boundary conditions has been previously reported by Tewari et al. (2010) for microscale dispersion modeling. Given the improved predictions of the WRF-urban and ENVI-met model chain, it was employed during the rest of our study.

\section{Results}

\section{a. Regional-scale and lake-breeze influence}

Future UHI conditions for August were obtained by downscaling the CAM output (averaged over 2076-81) through WRF-urban nesting for a 28-day simulation. An approximate measure of Chicago's UHI was needed to assess the impacts of projected variations in regional wind and lake breeze on the UHI, assuming no changes in urban LULC for the area. To determine the approximate present August conditions, temperature, wind speed, and pressure observations from ORD and MDW were averaged over a 10-yr period (2004-13), which showed reasonable agreement with 18 August 2013 average values (Table 4) for average and maximum temperatures (within a standard deviation) while the minimum temperature was somewhat lower on $18 \mathrm{Au}-$ gust. The wind speed and pressure were lower and higher, respectively, on 18 August 2013 than the average, which is characteristic of a synoptic environment favorable for the Chicago lake breeze that occurs on approximately $25 \%$ of August days (Laird et al. 2001). In all, 18 August was a "typical" strong lake-breeze day, with a lake breeze occurring at ORD, MDW, and DePaul. Henceforth, "present August" refers to 18 August 2013. For "future August," the 28-day WRF-urban simulation was scrutinized, and 5 days were identified that also had a strong lake breeze according to Laird et al.'s (2001) criteria at the three sites. The average of these five days was used as representative of a typical strong lakebreeze day and is referred to as future August.

To investigate the UHI intensity (the maximum nighttime difference between urban and rural temperatures), urban (box 1) and rural (box 2; LULC is predominantly cropland) areas, as defined in Fig. 5b, were selected. From box 1, the average temperature of urban LULC categories was obtained; grid cells overlying Lake Michigan were filtered out. To assess the influence of the lake breeze, meteorological conditions for future August from 1400 to 1700 LST for daytime and 0200 to 0500 LST for nighttime were averaged. According to the observations, these times include the daytime maximum and nighttime minimum temperatures for a typical day. Figures $5 \mathrm{a}$ and $5 \mathrm{~b}$ show the averaged surface temperature and winds for lake-breeze days of present and future August. Lake Michigan appears to play an important role in regulating the regional climate and UHI. For present August, the lake breeze shows signatures of cooler lake wind intrusion from western Lake Michigan into the CMA. The lake breeze is not strong enough to penetrate the entire CMA, although it plays a role in the effective elimination of UHI during the midday in present August.

In future August, significantly more heating occurs in the coastal areas and hinterland, causing surface winds to flow nearly perpendicular to the western shoreline at slightly elevated speeds as compared with present August. Significant cooling thus occurs in the coastal CMA, and the lake breeze penetrates nearly the entire CMA. Notwithstanding, the cooling is not effective beyond the coastal CMA, and box 1 is on average $1.8^{\circ} \mathrm{C}$ warmer than box 2 . Thus, the future UHI persists during the day in addition to during the nighttime (Fig. 6b).

TABLE 4. NWS ORD and MDW stations for 18 Aug 2013 vs decadal-average August period (2004-13). MSLP is mean sea level pressure. The "10-yr avg August" values are based on averaging variables for each of the decadal August months spanning 2004-13 and then averaging these 10 months to determine a 10 -yr average month.

\begin{tabular}{|c|c|c|c|c|c|c|}
\hline & \multicolumn{3}{|c|}{ ORD } & \multicolumn{3}{|c|}{ MDW } \\
\hline & \multirow[b]{2}{*}{18 Aug 2013} & \multicolumn{2}{|c|}{ 10-yr avg August } & \multirow[b]{2}{*}{18 Aug 2013} & \multicolumn{2}{|c|}{ 10-yr avg August } \\
\hline & & Avg & Std dev & & Avg & Std dev \\
\hline Avg temp $\left({ }^{\circ} \mathrm{C}\right)$ & 22.2 & 22.8 & 1.3 & 22.9 & 23.3 & 1.2 \\
\hline Max temp $\left({ }^{\circ} \mathrm{C}\right)$ & 27.2 & 28.1 & 1.2 & 27.2 & 28.0 & 1.2 \\
\hline Min temp $\left({ }^{\circ} \mathrm{C}\right)$ & 16.1 & 17.8 & 1.4 & 17.2 & 19.0 & 1.2 \\
\hline $\operatorname{Avg}$ ws $\left(\mathrm{m} \mathrm{s}^{-1}\right)$ & 2.2 & 3.4 & 0.2 & 2.3 & 3.5 & 0.3 \\
\hline Avg MSLP (hPa) & 1021 & 1015 & 1.0 & 1021 & 1015 & 1.1 \\
\hline
\end{tabular}



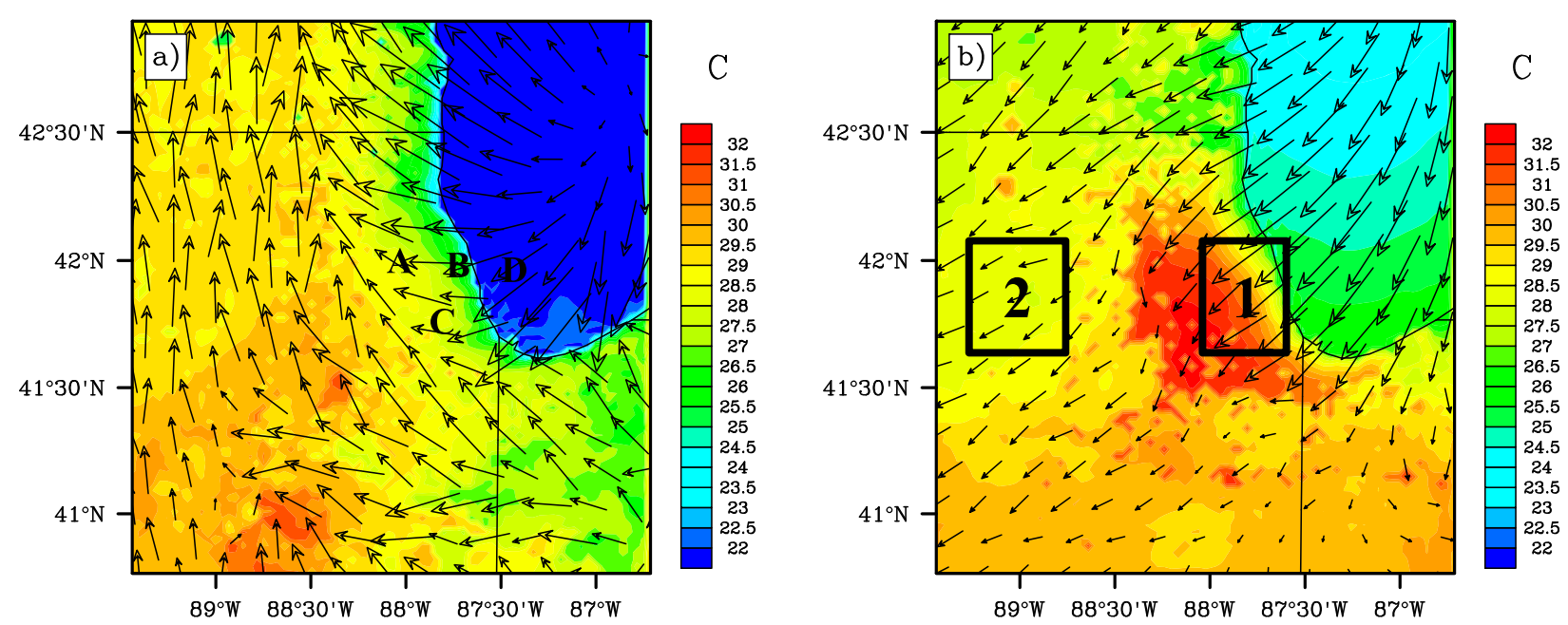

FIG. 5. Surface temperature $\left({ }^{\circ} \mathrm{C}\right)$ for the CMA overlaid by surface winds during daytime (1400-1700 LST), capturing the lake breeze at 3-km resolution. (a) Present August with locations used for land vs lake surface temperature comparisons: label A for ORD, B for DePaul University (nearest Chicago downtown), $\mathrm{C}$ for MDW, and D for the Lake Michigan surface. (b) Future August, with boxes 1 and 2 encompassing the areas used for UHI analysis: CMA core and an adjoining rural area, respectively.

Minor differences in synoptic winds between present and future August can account partially for changes in lake-breeze behavior, but enhanced surface heating in the future CMA cannot be excluded as a key factor. The impact of lake-breeze days for future climate may change because of the changes to the lake breeze, but their overall frequency remains the same, as based on the Laird et al. (2001) criteria, when applied to the 28day WRF-urban future simulation as well as August 2013 observations at ORD and MDW. This is due to the involvement of many governing factors, and the influence of some counteracts the others to maintain the frequency of lake-breeze events at the same level (Smith 2001).

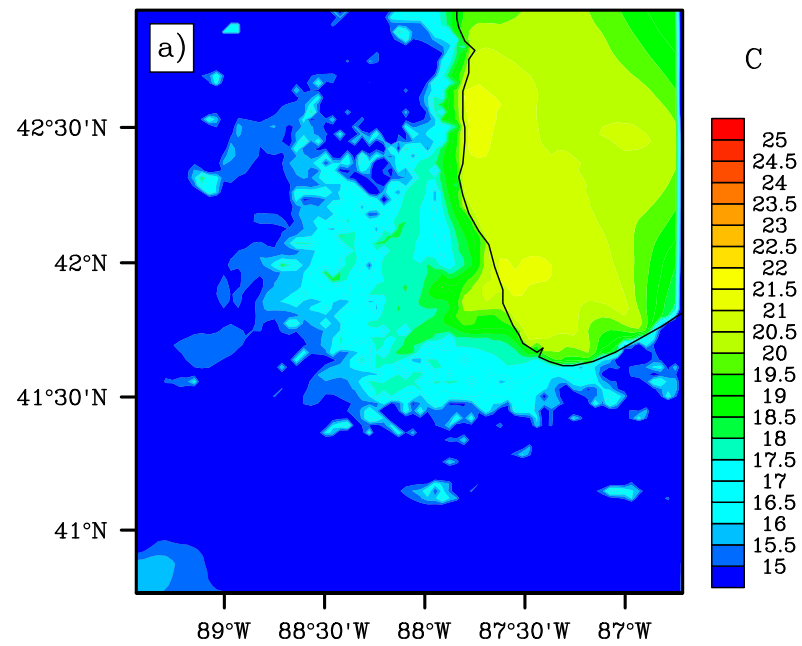

At night, typically the maximum UHI occurs and the lake breeze ceases. Figures $6 \mathrm{a}$ and $6 \mathrm{~b}$ show surface temperature during the nighttime for present and future August; note the strong UHI effect in both cases. In future August, the temperatures across the domain are approximately $4.5^{\circ} \mathrm{C}$ higher than those in present $\mathrm{Au}-$ gust. The calculated UHI intensities are $4.4^{\circ}$ and $4.9^{\circ} \mathrm{C}$ for present and future August, respectively. Therefore, nighttime conditions in CMA do appear to receive slightly elevated influence of global warming relative to the surrounding region. The relatively small increase of UHI intensity could arise because Lake Michigan regulates urban warming at this location, and hence this result ought to be viewed with circumspection.

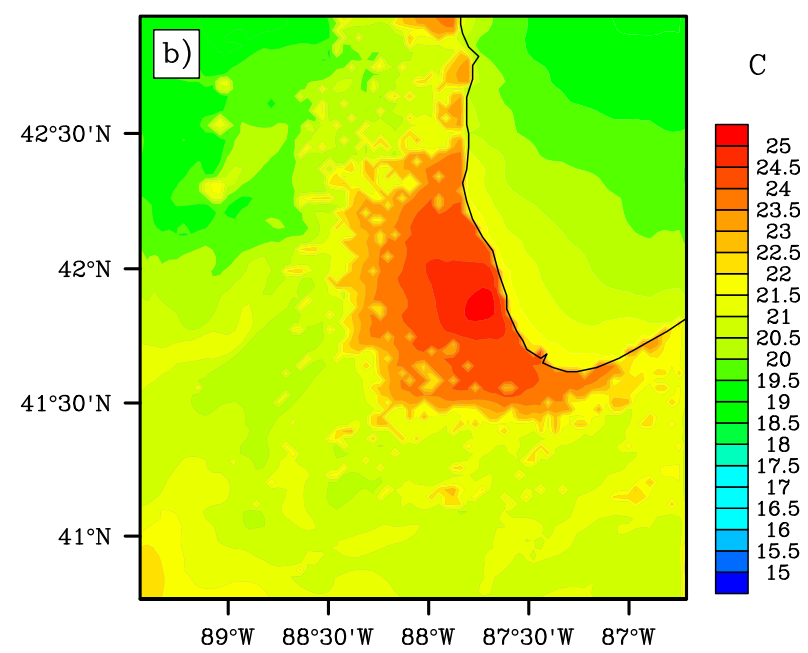

FIG. 6. Similar to Fig. 5, but for nighttime (0200-0500 LST): (a) present August and (b) future August. 

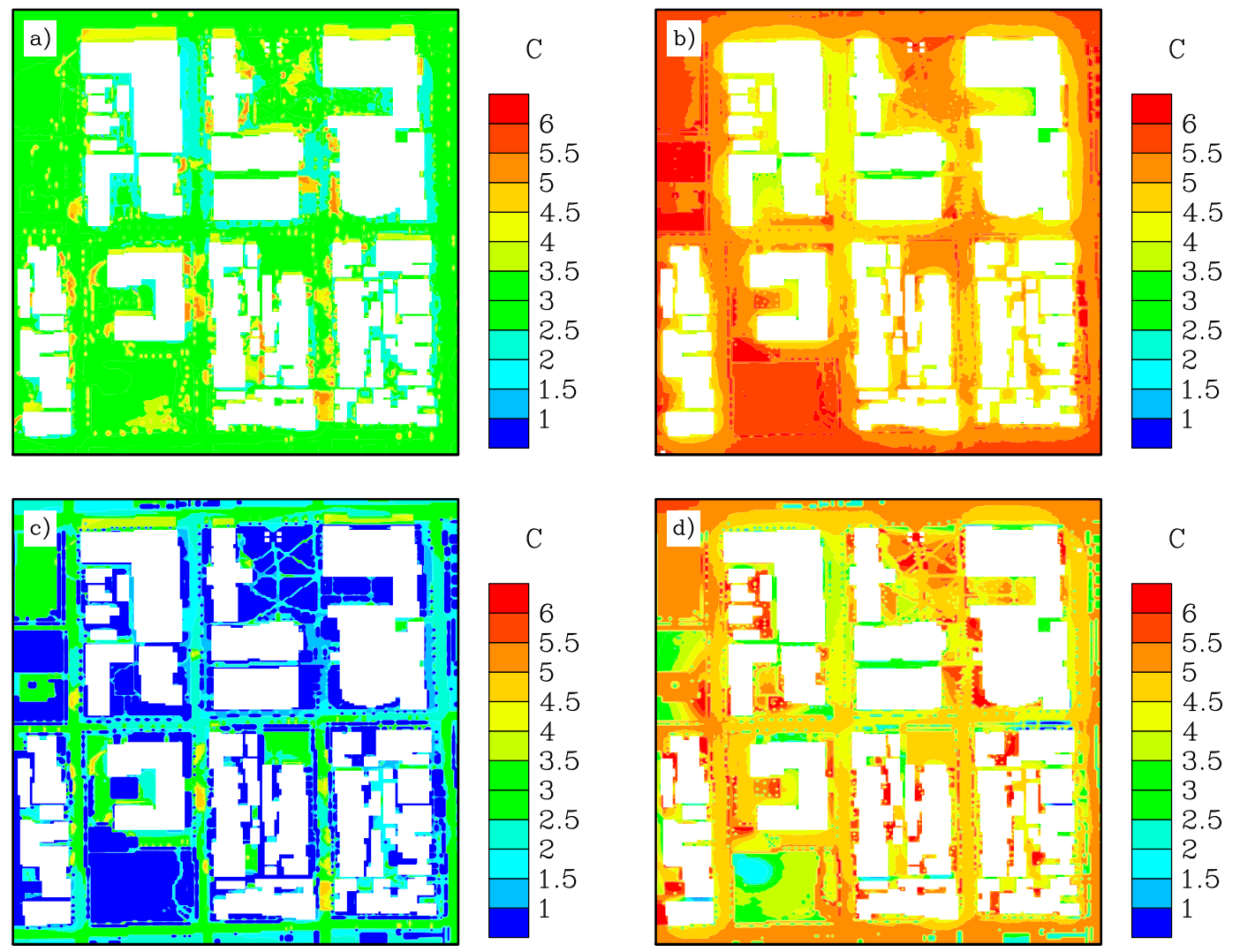

FIG. 7. The $\Delta T_{\mathrm{mrt}}=$ (future August $\left.T_{\mathrm{mrt}}\right)-$ (present August $T_{\mathrm{mrt}}$ ); white indicates building coverage. (a) At 1200 LST, sheltered regions of the domain (west of the buildings) with low wind speeds experience the most heating in future August. (b) At 0000 LST more significant rises of $T_{\mathrm{mrt}}$ occur than during daytime, corresponding to exacerbated UHI intensity of nighttime. (c) At 1200 LST, with more moist soil in future August than that in (a), significant decreases in $T_{\mathrm{mrt}}$ occur across the entire domain, especially for natural surfaces. (d) At 0000 LST, in future August more moist soil leads to an overall decrease in $T_{\mathrm{mrt}}$ as compared with (b), although the decrease is less significant than in (c).

\section{b. Microscale conditions}

ENVI-met simulations for future August were run for the same 2-day August period as present August, initialized by averaged future August output from the collocated WRF-urban grid cell. Results from the second day of the simulation (18 August) are described here. The Lincoln Park neighborhood that encompasses the microscale domain experiences elevated warming with 2-m ambient air temperature $T^{a}$ rising, on average, $4.7^{\circ} \mathrm{C}$. This exceeds the likely average surface temperature rise of $3^{\circ}-4^{\circ} \mathrm{C}$ predicted by GCMs for the RCP8.5 scenario (Stocker et al. 2013). Thus, urban dwellers are likely to experience exacerbated effects of climate change, and the GCM output alone cannot simulate the effect of climate on UHI.

An advantage of ENVI-met over coarser modeling techniques is its ability to predict the fine-resolution distribution of mean radiant temperature $T_{\mathrm{mrt}}$ in addition to the air temperature. The $T_{\mathrm{mrt}}$ is one of the most important variables for human thermal comfort, and it has high spatial variability. Although $T_{\mathrm{mrt}}$ is difficult to measure and model, ENVI-met employs an approximation method based on the steady-state assumption (Ali-Toudert and Mayer 2006). Figures 7a and 7b show the increase in $T_{\mathrm{mrt}}$ between present August and future August for 1200 and 0000 LST, respectively. The average increase in $T_{\mathrm{mrt}}$ at $1200 \mathrm{LST}$ is $3.0^{\circ} \mathrm{C}$, as compared with $5.1^{\circ} \mathrm{C}$ at $0000 \mathrm{LST}$. At night, already in the period of enhanced UHI intensity, urban dwellers will experience the most intense increase in $T_{\mathrm{mrt}}$ in future years. Some of the largest differences between present August and future August, noticeable at 1200 LST (Fig. 7a), occur in areas with the lowest wind speeds as a result of sheltering by urban obstacles. These areas feel minimal effect of slightly elevated wind speeds of a stronger lake breeze in future August and receive no benefit from wind transporting heat away through advection. Therefore, air and surface temperatures in these areas rise together. Urban design should account for frequent 

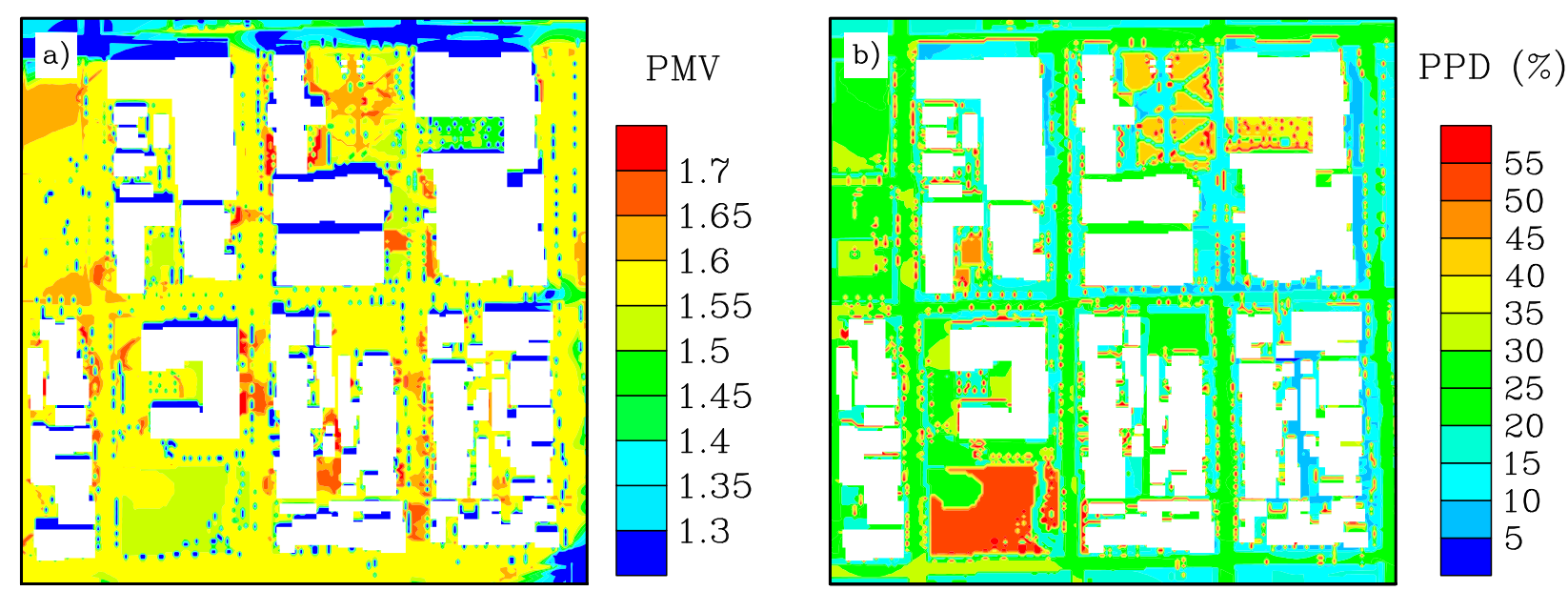

FIG. 8. As in Fig. 7a (1200 LST), but for differences in two pedestrian-comfort indicators. (a) An increase of PMV indicates that more pedestrians will experience thermal discomfort at a given location in future August. The scale typically ranges from -4 (coldest) to +4 (hottest) in outdoor environments so that changes ranging from 1 to 2 indicate conditions changing from "warm" to "hot" or "very hot." (b) The more comprehensible PPD increases shown here are statistically related to PMV. Since regions covered by natural surfaces were satisfactory to more people in present August, a larger portion of people can become thermally uncomfortable in future August.

seasonal wind conditions, like the northeasterly lake breeze in Chicago, and allow light breezes to penetrate the urban core to reap cooling benefits.

Future August for Figs. 7a and $7 \mathrm{~b}$ assumed relatively dry soil ( $\sim 25 \%$ moisture content) like for present $\mathrm{Au}-$ gust, but the future rise of $T_{\mathrm{mrt}}$ can be somewhat mitigated by using water-management strategies. In the simulation for future August that is used in Figs. $7 \mathrm{c}$ and $7 \mathrm{~d}$, a more-irrigated soil moisture content of $\sim 50 \%$ was assumed. The resultant $T_{\mathrm{mrt}}$ values are much lower above natural surfaces and also decrease slightly over other surfaces so that average $T_{\mathrm{mrt}}$, when compared with a dry present August, decreases by $0.5^{\circ} \mathrm{C}$ at 1200 LST and increases by just $4.6^{\circ} \mathrm{C}$ at $0000 \mathrm{LST}$ in future August. The above example briefly exemplifies the broad utility of the model chain in sustainable urban design.

\section{c. Pedestrian comfort}

The ENVI-met results were directly fed into the PMV submodel. At all locations within this microscale domain, PMV increases by more than 1 unit of scale (Fig. 8a), with the lowest increases occurring in areas with maximum wind speeds and completely shaded areas north of buildings. This again shows that moderate winds have a tendency to produce higher comfort by moderating future increases in heat-stress indicators, as was demonstrated in the preceding section for $T_{\mathrm{mrt}}$. To inform readers who are unfamiliar with the PMV scale, Fig. $8 \mathrm{~b}$ displays the corresponding difference in PPD, which is a measure of the increase in the percentage of any given population that experiences thermal discomfort.
Natural surfaces exhibit the largest increase in PPD because most people in present August were comfortable there, and hence increases in $T_{a}$ and $T_{\mathrm{mrt}}$ have greater relative impact therein. The rises in PPD are substantial at $1200 \mathrm{LST}$, with area-averaged values showing that $92.0 \%$ of people are dissatisfied in future August as compared with $67 \%$ in present August. Throughout nearly the entire domain in future August, over $90 \%$ of the population experiences thermal discomfort, excluding only a few completely shaded areas. Any advantage the lake breeze may have had in providing manageable thermal comfort in present August is eliminated by the increases in $T_{a}$ and $T_{\mathrm{mrt}}$ in future August (which overshadow the advantage of the slight increase in the lake breeze). Such a significant decrease in human comfort within urban outdoor space during daytime is a potential serious threat and reiterates the need for developing climate-change adaptation strategies for urban spaces.

\section{d. Building energy}

The simple building-energy model was applied to the McGowan South (MS) Building of DePaul University located near the center of the ENVI-met domain to obtain results for present and future August (Fig. 9). During the nighttime, like most nonresidential real estate, this building is unoccupied, and therefore the model's exclusive application to daytime does not present a major problem. Figure 9 shows a considerable $(\sim 26.0 \%)$ increase in daytime (0700-1700 LST) cooling load as a result of the changes in microclimatic conditions. The peak cooling load occurs at 1200 LST because 


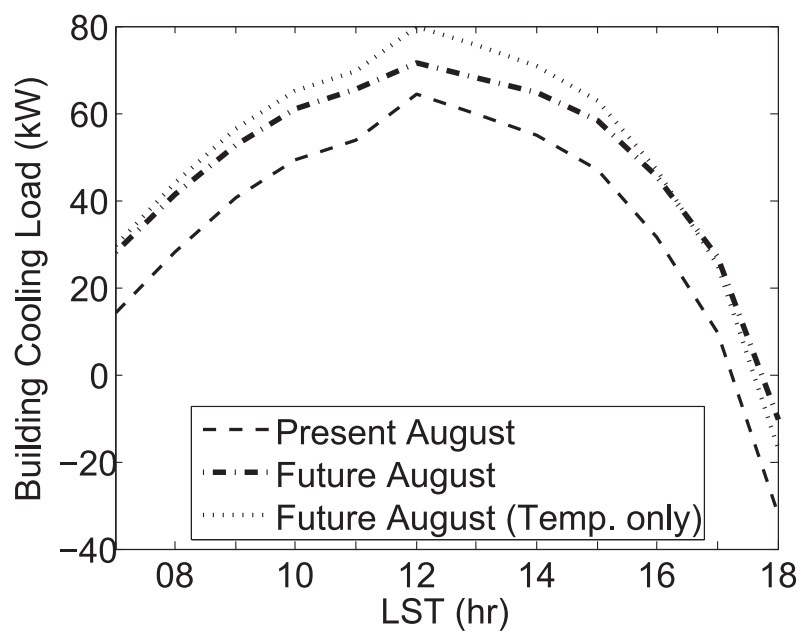

FIG. 9. Daytime cooling load for MS predicted by BEM for present August, future August, and future August temperatures combined with present August winds. The latter was done to assess the relative cooling impact of the lake breeze.

most of the building's surface area receives direct solar irradiance at this time. The peak load for future August is $11.2 \%$ greater than that for present August.

The effects of the lake breeze on building energy were studied by considering future August climate with an increase in temperature only. The same wind conditions from present August were fed into the model along with future August temperatures, revealing that the slightly enhanced lake breeze in the future can have a significant cooling impact; without the enhanced breeze, daytime cooling load was predicted to increase $35.7 \%$ in future August (Fig. 9). Note that the increases in wind speed at the DePaul site $\left(\sim 0.3 \mathrm{~m} \mathrm{~s}^{-1}\right)$ are within the range of error typically found in mesoscale models and in our own case (Table 1). Still, the predicted rise in temperature will dominate, barring any major changes in wind speed, and an increase in cooling demand is predicted for the future. Other factors affecting the cooling load, such as a building's inhabitants, equipment, windows, and materials, are expected to cause larger overall cooling loads in both present and future August. Future changes in such nonclimatic factors may either offset or heighten the energy demand caused by microclimate, the evaluation of which is outside the scope of our study.

\section{Discussion and conclusions}

A multimodel nesting procedure was used to assess the effects of climate change on UHI, the study area being the Chicago metropolitan area. The model chain included a global climate model (CAM at $\sim 200-\mathrm{km}$ resolution), as well as mesoscale (nested WRF-urban spanning from 9- to $0.333-\mathrm{km}$ resolution) and microscale
(ENVI-met at 2-m resolution) models, which were used to delve into a range of scales that were hitherto unattained. The mesoscale and microscale models were validated, respectively, using observations from existing meteorological stations and those from a dedicated urban miniature field campaign. The evaluation of WRF-urban and ENVImet coupling showed the utility of ENVI-met in the model chain. ENVI-met, however, is unable to adjust dynamically to shifts in mesoscale circulation because it is driven by a steady meteorological input. Performance during relatively steady conditions confirmed that it is capable of simulating the average differences between future and present. ENVI-met coupled with WRF-urban outperformed ENVI-met driven by observations, the latter being the status quo. The grid-averaged variables produced by WRF-urban are more representative inputs for ENVI-met than are those that are based on observations.

The nested-modeling approach proposed and used is portable to other cities, requiring only the adjustment of model parameters and inputs to suit the locality. The models used are available as easily accessible freeware, although exorbitant computational cost currently limits their utility for operational applications. WRF-urban simulations, which utilize boundary conditions that are based on a 5-day period within the present (15-19 August 2013) and a single future climate scenario (RCP8.5) rather than ensemble approaches, may introduce uncertainties. Nonetheless, they do provide a worst-case context for considering potential climate-change effects as well as a means to evaluate a previously untested method. The submodel, which was developed for assessing the buildingenergy budget as well as changes in building power consumption due to the effects of climate change, can be extended in future work to include additional building details and a higher degree of thermodynamic sophistication.

The application of the model chain to the specific case of Chicago's UHI provided insights on the role of the lake breeze. While the lake breeze in the future climate may penetrate farther onshore than in the present climate, lake-breeze events will neither increase in frequency of occurrence nor provide relief from an intensified daytime UHI. The heightening of overall air temperatures in the CMA in future August could make Chicago a less livable and sustainable city. Investigations at microscales revealed that any benefits from slightly increased average wind speed at DePaul in the future August climate are seriously outweighed by increased air temperatures that lead to decreased pedestrian comfort and increased energy consumption.

This paper expands upon the scope of results that was achieved in the single-scale study of Smith and Roebber (2011) for Chicago's UHI. As numerical modeling capabilities continue to improve at all scales, higher 
accuracy, lower computational cost, and easier coupling of models will allow significant improvements to nested multiscale modeling, thus providing a promising tool for scientists, engineers, and policy makers to evaluate climate-change impacts and adaptation strategies for urban areas. Upscaling from the microscale into the mesoscale, as well as developing microscale models that are amenable to unsteady synoptic inputs, will also be promising future topics within the context and theme of this paper.

Acknowledgments. This research was funded by NSF Grant 0924592, the Notre Dame Environmental Change Initiative, and the Sustainability Office of the City of Chicago. We gratefully acknowledge DePaul University's Facility Operations for access to experimental locations, R. Scott Coppersmith and Raffaele Quarta for their support during the experimental campaign, and Temistocle Grenga for his contributions to the development of the building-energy submodel.

\section{APPENDIX A}

\section{List of Acronyms}

$\begin{array}{ll}\text { AH } & \text { Anthropogenic heat } \\ \text { BEM } & \text { Building Energy Model } \\ \text { BEP } & \text { Building Energy Parameterization } \\ \text { CAM } & \text { Community Atmosphere Model } \\ \text { CFD } & \text { Computational fluid dynamics } \\ \text { CMA } & \text { Chicago metropolitan area } \\ \text { GCM } & \text { Global climate model } \\ \text { GHG } & \text { Greenhouse gas } \\ \text { HVAC } & \text { Heating, ventilation, and air conditioning } \\ \text { IPCC } & \text { Intergovernmental Panel on Climate Change } \\ \text { LULC } & \text { Land use/land cover } \\ \text { MAE } & \text { Mean absolute error } \\ \text { MC } & \text { Munroe Courtyard } \\ \text { MDW } & \text { Midway International Airport } \\ \text { MS } & \text { McGowan South Building } \\ \text { NARR } & \text { North American Regional Reanalysis } \\ \text { NLCD } & \text { National Land Cover Database } \\ \text { NWS } & \text { National Weather Service } \\ \text { ORD } & \text { O'Hare International Airport } \\ \text { PMV } & \text { Predicted mean vote } \\ \text { PPD } & \text { Predicted percentage dissatisfied } \\ \text { RCM } & \text { Regional climate model } \\ \text { RCP8.5 } & \text { Representative concentration pathway of } \\ & \text { 8.5W }{ }^{-2} \\ \text { UCM } & \text { Urban canopy model } \\ \text { UCP } & \text { Urban canopy parameterization } \\ \text { UHI } & \text { Urban heat island } \\ \text { WRF } & \text { Weather Research and Forecasting Model }\end{array}$

\section{APPENDIX B}

\section{Building Energy Model Nomenclature}

A Surface area of face $\left(\mathrm{m}^{2}\right)$

$h^{c} \quad$ Total convection coefficient $\left(\mathrm{W} \mathrm{m}^{-2} \mathrm{~K}^{-1}\right)$

$k \quad$ Thermal conductivity $\left(\mathrm{W} \mathrm{m}^{-1} \mathrm{~K}^{-1}\right)$

$L \quad$ Thickness of insulating layer (m)

$Q^{\text {sys }} \quad$ Air-conditioning system's output (W)

$q^{\text {lw }} \quad$ Longwave radiative flux $\left(\mathrm{W} \mathrm{m}^{-2}\right)$

$q^{\mathrm{sw}} \quad$ Shortwave radiative flux $\left(\mathrm{W} \mathrm{m}^{-2}\right)$

$V \quad$ Wind speed $\left(\mathrm{m} \mathrm{s}^{-1}\right)$

$\alpha \quad$ Albedo

$\varepsilon \quad$ Emissivity

$\beta \quad$ Angle of incidence of wind $\left(^{\circ}\right)$

$\sigma \quad$ Stefan-Boltzmann constant $\left(\mathrm{W} \mathrm{m}^{-2} \mathrm{~K}^{-4}\right)$

$T^{a} \quad$ Exterior ambient air temperature $(\mathrm{K})$

$T^{s} \quad$ Exterior surface temperature (K)

$\tau^{r} \quad$ Interior room temperature $(\mathrm{K})$

$\tau^{s} \quad$ Interior surface temperature $(\mathrm{K})$

\section{REFERENCES}

Ali-Toudert, F., and H. Mayer, 2006: Numerical study on the effects of aspect ratio and orientation of an urban street canyon on outdoor thermal comfort in hot and dry climate. Build. Environ., 41, 94-108, doi:10.1016/j.buildenv.2005.01.013.

Baik, J.-J., S.-B. Park, and J.-J. Kim, 2009: Urban flow and dispersion simulations using a CFD model coupled to a mesoscale model. J. Appl. Meteor. Climatol., 48, 1667-1681, doi:10.1175/2009JAMC2066.1.

Bouyer, J., C. Inard, and M. Musy, 2011: Microclimatic coupling as a solution to improve building energy simulation in an urban context. Energy Build., 43, 1549-1559, doi:10.1016/ j.enbuild.2011.02.010.

Brown, M., and Coauthors, 2001: Multiscale modeling of air flow in Salt Lake City and surrounding region. Proc. ASCE Structures Congress 2001, Washington, DC, American Society of Civil Engineers, doi:10.1061/40558(2001)96.

Bruse, M., and H. Fleer, 1998: Simulating surface-plant-air interactions inside urban environment with a three dimensional numerical model. Environ. Modell. Software, 13, 373-384, doi:10.1016/S1364-8152(98)00042-5.

Chen, F., and Coauthors, 2011: The integrated WRF/urban modelling system: Development, evaluation, and applications to urban environmental problems. Int. J. Climatol., 31, 273-288, doi:10.1002/joc. 2158 .

— modeling urban weather and climate. Bull. Amer. Meteor. Soc., 93, 1725-1728, doi:10.1175/BAMS-D-11-00217.1.

Chen, Y., and N. H. Wong, 2006: Thermal benefits of city parks. Energy Build., 38, 105-120, doi:10.1016/j.enbuild.2005.04.003.

Ching, J. K. S., 2013: A perspective on urban canopy layer modeling for weather, climate and air quality applications. Urban Climate, 3, 13-39, doi:10.1016/j.uclim.2013.02.001.

Chow, W. T. L., and A. J. Brazel, 2012: Assessing xeriscaping as a sustainable heat island mitigation approach for a desert city. Build. Environ., 47, 170-181, doi:10.1016/ j.buildenv.2011.07.027. 
— R. L. Pope, C. A. Martin, and A. J. Brazel, 2011: Observing and modeling the nocturnal park cool island of an arid city: Horizontal and vertical impacts. Theor. Appl. Climatol., 103, 197-211, doi:10.1007/s00704-010-0293-8.

Coffee, J. E., J. Parzen, M. Wagstaff, and R. S. Lewis, 2010: Preparing for a changing climate: The Chicago Climate Action Plan's adaptation strategy. J. Great Lakes Res., 36, 115-117, doi:10.1016/j.jglr.2009.11.011.

Coirier, W. J., D. M. Fricker, M. Furmanczyk, and S. Kim, 2005: A computational fluid dynamics approach for urban area transport and dispersion modeling. Environ. Fluid Mech., 5, 443 479, doi:10.1007/s10652-005-0299-4.

Conry, P., A. Sharma, H. J. S. Fernando, M. Potosnak, L. S. Leo, and J. Hellmann, 2014a: Multi-scale simulations of climatechange influence on Chicago heat island. Proc. Fourth Joint US-European Fluids Engineering Division Summer Meeting, Chicago, IL, American Society of Mechanical Engineers, doi:10.1115/FEDSM2014-21581.

,-- , M. Potosnak, J. Hellmann, and H. J. S. Fernando, 2014b: Multi-scale study of Chicago heat island and the impacts of climate change. Proc. 11th Symp. on the Urban Environment, Atlanta, GA, Amer. Meteor. Soc., 3.6. [Available online at https://ams.confex.com/ams/94Annual/webprogram/ Paper235996.html.]

Crawley, D. B., J. W. Hand, M. Kummert, and B. T. Griffith, 2008: Contrasting the capabilities of building energy performance simulation programs. Build. Environ., 43, 661-673, doi:10.1016/j.buildenv.2006.10.027.

Dallman, A., S. Di Sabatino, and H. J. S. Fernando, 2013: Flow and turbulence in an industrial/suburban roughness canopy. Environ. Fluid Mech., 13, 279-307, doi:10.1007/ s10652-013-9274-7.

Dimitrova, R., J. Sini, K. Richards, M. Schatzmann, M. Weeks, E. Perez Garcia, and C. Borrego, 2009: Influence of the thermal effects on the wind field with the urban environment. Bound.-Layer Meteor., 131, 223-243, doi:10.1007/ s10546-009-9368-4.

DOE, 2013: EnergyPlus engineering reference: The reference to EnergyPlus calculations (in case you want or need to know). U.S. Department of Energy Rep., 1417 pp. [Available online at http://apps1.eere.energy.gov/buildings/energyplus/pdfs/ engineeringreference.pdf.]

Emmanuel, R., and H. J. S. Fernando, 2007: Urban heat islands in humid and arid climates: Role of urban form and thermal properties in Colombo, Sri Lanka and Phoenix, USA. Climate Res., 34, 241-251, doi:10.3354/cr00694.

Emmel, M. G., M. O. Abadie, and N. Mendes, 2007: New external convective heat transfer coefficient correlations for isolated low-rise buildings. Energy Build., 39, 335-342, doi:10.1016/ j.enbuild.2006.08.001.

Fangers, P. O., 1970: Thermal Comfort: Analysis and Applications in Environmental Engineering. Danish Technical Press, 244 pp.

Fernando, H. J. S., S. M. Lee, J. Anderson, M. Princevac, E. R. Pardyjak, and S. Grossman-Clarke, 2001: Urban fluid mechanics: Air circulation and contaminant dispersion in cities. Environ. Fluid Mech., 1, 107-164, doi:10.1023/ A:1011504001479.

, D. Zajic, S. Di Sabatino, R. Dimitrova, B. Hedquist, and A. Dallman, 2010: Flow, turbulence, and pollutant dispersion in urban atmospheres. Phys. Fluids, 22, 051301, doi:10.1063/ 1.3407662 .

_- R. Dimitrova, and S. Sentic, 2012: Climate change meets urban environment. National Security and Human Health
Implications of Climate Change, H. J. S. Fernando, Z. B. Klaić, and J. L. McCulley, Eds., Springer, 115-134.

Frank, T., 2005: Climate change impacts on building heating and cooling energy demand in Switzerland. Energy Build., 37, 1175-1185, doi:10.1016/j.enbuild.2005.06.019.

Franke, J., A. Hellsten, H. Schlünzen, and B. Carissimo, 2007: Best practice guideline for the CFD simulation of flows in the urban environment. COST Office Rep., 51 pp.

Früh, B., and Coauthors, 2011: Estimation of climate-change impacts on the urban heat load using an urban climate model and regional climate projections. J. Appl. Meteor. Climatol., 50, 167-184, doi:10.1175/2010JAMC2377.1.

Georgescu, M., P. E. Morefield, B. G. Bierwagen, and C. P. Weaver, 2014: Urban adaptation can roll back warming of emerging megapolitan regions. Proc. Natl. Acad. Sci. USA, 111, 2909-2914, doi:10.1073/pnas.1322280111.

Gowardhan, A. A., E. R. Pardyjak, I. Senocak, and M. J. Brown, 2011: A CFD-based wind solver for an urban fast response transport and dispersion model. Environ. Fluid Mech., 11, 439-464, doi:10.1007/s10652-011-9211-6.

Grimmond, C. S. B., T. S. King, M. Roth, and T. R. Oke, 1998: Aerodynamic roughness of urban areas derived from wind observations. Bound.-Layer Meteor., 89, 1-24, doi:10.1023/ A:1001525622213.

_ - and Coauthors, 2011: Initial results from phase 2 of the International Urban Energy Balance Model Comparison. Int. J. Climatol., 31, 244-272, doi:10.1002/joc.2227.

Guhathakurta, S., and P. Gober, 2010: Residential land use, the urban heat island, and water use in Phoenix: A path analysis. J. Plann. Educ. Res., 30, 40-50, doi:10.1177/ 0739456 X10374187.

Gutiérrez, E., J. E. González, R. Bornstein, M. Arend, and A. Martilli, 2013: A new modeling approach to forecast building energy demands during extreme heat events in complex cities. J. Sol. Energy Eng., 135, 040906, doi:10.1115/ 1.4025510 .

Hamdi, R., H. Van de Vyver, R. De Troch, and P. Termonia, 2013: Assessment of three dynamical urban climate downscaling methods: Brussels's future urban heat island under an A1B emission scenario. Int. J. Climatol., 34, 978-999, doi:10.1002/ joc.3734.

Harlan, S. L., A. J. Brazel, L. Prashad, W. L. Stefanov, and L. Larsen, 2006: Neighborhood microclimates and vulnerability to heat stress. Soc. Sci. Med., 63, 2847-2863, doi:10.1016/ j.socscimed.2006.07.030.

Hayhoe, K., J. VanDorn, T. Croley II, N. Schlegal, and D. Wuebbles, 2010: Regional climate change projections for Chicago and the US Great Lakes. J. Great Lakes Res., 36 (Suppl.), 7-21, doi:10.1016/j.jglr.2010.03.012.

Hedquist, B. C., and A. J. Brazel, 2014: Seasonal variability of temperatures and outdoor human comfort in Phoenix, Arizona, U.S.A. Build. Environ., 72, 377-388, doi:10.1016/ j.buildenv.2013.11.018.

Janjić, Z. I., 1994: The step-mountain eta model: Further developments of the convection, viscous sublayer, and turbulence closure schemes. Mon. Wea. Rev., 122, 927-945, doi:10.1175/1520-0493(1994)122<0927:TSMECM>2.0.CO;2.

Jendritzky, G., 1990: Regional bio-climatological assessment procedure using mesoscale bioclimate maps as example (in German). Methodik zur räumlichen Bewertung der thermischen Komponente im Bioklima des Menschen: Fortgeschriebenes Klima-Michel- Modell, H. Schirmer et al., Eds., Akademie für Raumforschung und Landesplanung, 7-69. 
Keeler, J. M., and D. A. R. Kristovich, 2012: Observations of urban heat island influence on lake-breeze frontal movement. J. Appl. Meteor. Climatol., 51, 702-710, doi:10.1175/ JAMC-D-11-0166.1.

Kennedy, C., S. Pincetl, and P. Bunje, 2011: The study of urban metabolism and its applications to urban planning and design. Environ. Pollut., 159, 1965-1973, doi:10.1016/ j.envpol.2010.10.022.

Kusaka, H., and F. Kimura, 2004: Coupling a single-layer urban canopy model with a simple atmospheric model: Impact of urban heat island simulation for an idealized case. J. Meteor. Soc. Japan, 82, 67-80, doi:10.2151/jmsj.82.67.

—, M. Hara, and Y. Takane, 2012: Urban climate projection by the WRF model at 3-km horizontal grid increment: Dynamical downscaling and predicting heat stress in the 2070's August for Tokyo, Osaka, and Nagoya metropolises. J. Meteor. Soc. Japan, 90B, 47-63, doi:10.2151/jmsj.2012-B04.

Laird, N. F., D. A. R. Kristovich, X. Liang, R. W. Arritt, and K. Labas, 2001: Lake Michigan lake breezes: Climatology, local forcing, and synoptic environment. J. Appl. Meteor., 40, 409-424, doi:10.1175/1520-0450(2001)040<0409:LMLBCL > 2.0.CO;2.

Lemonsu, A., and V. Masson, 2002: Simulation of a summer urban breeze over Paris. Bound.-Layer Meteor., 104, 463-490, doi:10.1023/A:1016509614936.

_ , R. Kounkou-Arnaud, J. Desplat, J. Salagnac, and V. Masson, 2013: Evolution of the Parisian urban climate under a global changing climate. Climatic Change, 116, 679-692, doi:10.1007/ s10584-012-0521-6.

Leung, L. R., Y. Kuo, and J. Tribbia, 2006: Research needs and directions of regional climate modeling using WRF and CCSM. Bull. Amer. Meteor. Soc., 87, 1747-1751, doi:10.1175/ BAMS-87-12-1747.

Li, D., and E. Bou-Zeid, 2013: Synergistic interaction between urban heat islands and heat waves: The impact in cities is larger than the sum of its parts. J. Appl. Meteor. Climatol., 52, 2051-2064, doi:10.1175/JAMC-D-13-02.1.

Li, K., and Coauthors, 2007: Development of a framework for quantifying the environmental impacts of urban development and construction practices. Environ. Sci. Technol. Lett., 41, 5130-5136, doi:10.1021/es062481d.

Lin, C.-Y., F. Chen, J. C. Huang, W.-C. Chen, Y.-A. Liou, W.-N. Chen, and S.-C. Liu, 2008: Urban heat island effect and its impact on boundary layer development and land-sea circulation over northern Taiwan. Atmos. Environ., 42, 5635-5649, doi:10.1016/ j.atmosenv.2008.03.015.

Lindberg, F., B. Holmer, and S. Thorsson, 2008: SOLWEIG $1.0-$ Modelling spatial variations of 3D radiant fluxes and mean radiant temperature in complex urban settings. Int J. Biometeor., 52, 697-713, doi:10.1007/s00484-008-0162-7.

Liu, Y., and D. J. Harris, 2007: Full-scale measurements of convective coefficient on external surface of a low-rise building in sheltered conditions. Build. Environ., 42, 2718-2736, doi:10.1016/j.buildenv.2006.07.013.

Ma, J., X. Li, and Y. Zhu, 2012: A simplified method to predict the outdoor thermal environment in residential district. Build. Simul., 5, 157-167, doi:10.1007/s12273-012-0079-2.

Maggiotto, G., R. Buccolieri, M. A. Santo, L. S. Leo, and S. Di Sabatino, 2014: Validation of temperature-perturbation and CFD-based modelling for the prediction of the thermal environment: The Lecce (IT) case study. Environ. Modell. Software, 60, 69-83, doi:10.1016/j.envsoft.2014.06.001.

Manfred, K., and T. Schmidt, 2008: Radiation effects on exterior surfaces. Proc. Eighth Symp. on Building Physics in Nordic
Countries, Vol. 2, Copenhagen, Denmark, Technical University of Denmark, 207-212.

Martilli, A., A. Clappier, and M. W. Rotach, 2002: An urban surface exchange parameterisation for mesoscale models. Bound.-Layer Meteor., 104, 261-304, doi:10.1023/ A:1016099921195.

Masson, V., 2000: A physically-based scheme for the urban energy budget in atmospheric models. Bound.-Layer Meteor., 94, 357-397, doi:10.1023/A:1002463829265.

Matzarakis, A., F. Rutz, and H. Mayer, 2007: Modelling radiation fluxes in simple and complex environments-Application of the RayMan model. Int. J. Biometeor., 51, 323-334, doi:10.1007/s00484-006-0061-8.

Mayer, H., and P. Höppe, 1987: Thermal comfort of man in different urban environments. Theor. Appl. Climatol., 38, 43-49, doi:10.1007/BF00866252.

Mian, O. S., J. M. Thom, L. P. Ardigò, M. V. Narici, and A. E. Minetti, 2006: Metabolic cost, mechanical work, and efficiency during walking in young and older men. Acta Physiol., 186, 127-139, doi:10.1111/j.1748-1716.2006.01522.x.

Müller, N., W. Kuttler, and A. Barlag, 2014: Counteracting urban climate change: Adaptation measures and their effect on thermal comfort. Theor. Appl. Climatol., 115, 243-257, doi:10.1007/s00704-013-0890-4.

Niyogi, D., P. Pyle, M. Lei, S. P. Arya, C. M. Kishtawal, M. Shepherd, F. Chen, and B. Wolfe, 2011: Urban modification of thunderstorms: An observational storm climatology and model case study for the Indianapolis urban region. J. Appl. Meteor. Climatol., 50, 1129-1144, doi:10.1175/ 2010JAMC1836.1.

Ohashi, Y., Y. Kikegawa, T. Ihara, and N. Sugiyam, 2014: Numerical simulations of outdoor heat stress index and heat disorder risk in the 23 wards of Tokyo. J. Appl. Meteor. Climatol., 53, doi:10.1175/JAMC-D-13-0127.1.

Oke, T. R., 1978: Inadvertent climate modification. Boundary Layer Climates, T. R. Oke, Ed., Methuen and Co., 229-267.

, 2006: Towards better scientific communication in urban climate. Theor. Appl. Climatol., 84, 179-190, doi:10.1007/ s00704-005-0153-0.

Oleson, K. W., A. Monaghan, O. Wilhelmi, M. Barlage, N. Brunsell, J. Feddema, L. Hu, and D. F. Steinhoff, 2010: Interactions between urbanization, heat stress, and climate change. Climatic Change, 129, 525-541, doi:10.1007/ s10584-013-0936-8.

Park, S. Y., H. J. S. Fernando, and S. C. Yoon, 2014: Simulation of flow and turbulence in the Phoenix area using a modified urbanized model. Meteor. Appl., 21, 948-962, doi:10.1002/ met.1442.

Rosenzweig, C., W. D. Solecki, L. Parshall, M. Chopping, G. Pope, and R. Goldberg, 2005: Characterizing the urban heat island in current and future climates in New Jersey. Environ. Hazards, 6, 51-62, doi:10.1016/j.hazards.2004.12.001.

Salamanca, F., A. Krpo, A. Martilli, and A. Clappier, 2010: A new building energy model coupled with urban canopy parameterization for urban climate simulations-Part I. Formulation, verification, and sensitivity analysis of the model. Theor. Appl. Climatol., 99, 331-344, doi:10.1007/s00704-009-0142-9.

, A. Martilli, M. Tewari, and F. Chen, 2011: A study of the urban boundary layer using different urban parameterizations and high-resolution urban canopy parameters with WRF. J. Appl. Meteor. Climatol., 50,1107-1128, doi:10.1175/2010JAMC2538.1. - - and C. Yagüe, 2012: A numerical study of the urban heat island over Madrid during the DESIREX (2008) 
campaign with WRF and an evaluation of simple mitigation strategies. Int. J. Climatol., 32, 2372-2386, doi:10.1002/joc.3398.

Sharma, A., H. J. S. Fernando, J. Hellmann, and F. Chen, 2014: Sensitivity of WRF model to urban parameterizations, with applications to Chicago metropolitan urban heat island. Proc. Fourth Joint US-European Fluids Engineering Division Summer Meeting, Chicago, IL, American Society of Mechanical Engineers, 10 pp., doi:10.1115/FEDSM2014-21292.

Smith, B. B., 2001: Development of a lake breeze forecast methodology for northern Michigan. Natl. Wea. Bull., 25 $(3,4), 47-52$.

Smith, K. R., and P. J. Roebber, 2011: Green roof mitigation potential for a proxy future climate scenario in Chicago, Illinois. J. Appl. Meteor. Climatol., 50, 507-522, doi:10.1175/ 2010JAMC2337.1.

Solomon, S., and Coauthors, Eds., 2007: Climate Change 2007: The Physical Science Basis. Cambridge University Press, 1007 pp.

Stocker, T. F., and Coauthors, Eds., 2013: Climate Change 2013: The Physical Science Basis. Cambridge University Press, $950 \mathrm{pp}$.

Stone, B., J. Vargo, and D. Habeeb, 2012: Managing climate change in cities: Will climate action plans work? Landscape Urban Plann., 107, 263-271, doi:10.1016/j.landurbplan.2012.05.014.

Taha, H., 1999: Modifying a mesoscale meteorological model to better incorporate urban heat storage: A bulk-parameterization approach. J. Appl. Meteor., 38, 466-473, doi:10.1175/ 1520-0450(1999)038<0466:MAMMMT>2.0.CO;2.

Tewari, M., H. Kusaka, F. Chen, W. J. Coirier, S. Kim, A. A. Wyszogrodzki, and T. T. Warner, 2010: Impact of coupling a microscale computational fluid dynamics model with a mesoscale model on urban contaminant transport and dispersion. Atmos. Res., 96, 656-664, doi:10.1016/ j.atmosres.2010.01.006.

Thorsson, S., M. Lindqvist, and S. Lindqvist, 2004: Thermal bioclimatic conditions and patterns of behavior in an urban park in Göteborg, Sweden. Int. J. Biometeor., 48, 149-156, doi:10.1007/s00484-003-0189-8.

— , F. Lindberg, J. Björklund, B. Holmer, and D. Rayner, 2011: Potential changes in outdoor thermal comfort conditions in Gothenburg, Sweden due to climate change: The influence of urban geometry. Int. J. Climatol., 31, 324-335, doi:10.1002/ joc. 2231.

Vos, P. E. J., B. Maiheu, J. Vankerkom, and S. Janssen, 2013: Improving local air quality in cities: To tree or not to tree? Environ. Pollut., 183, 113-122, doi:10.1016/j.envpol.2012.10.021.

Wang, Y., L. R. Leung, J. L. McGregor, D. Lee, W. Wang, Y. Ding, and F. Kimura, 2004: Regional climate modeling: Progress, challenges, and prospects. J. Meteor. Soc. Japan, 82, 15991628, doi:10.2151/jmsj.82.1599.

Wilby, R. L., 2003: Past and projected trends in London's urban heat island. Weather, 58, 251-260, doi:10.1256/wea.183.02.

Wilks, D. S., 1995: Statistical Methods in the Atmospheric Sciences. 2nd ed. Academic Press, 464 pp.

Willmott, C. J., 1982: Some comments on the evaluation of model performance. Bull. Amer. Meteor. Soc., 63, 1309-1313, doi:10.1175/1520-0477(1982)063<1309:SCOTEO > 2.0.CO;2.

— S. M. Robeson, and K. Matsuura, 2012: A refined index of model performance. Int. J. Climatol., 32, 2088-2094, doi:10.1002/ joc.2419.

Zajic, D., H. J. S. Fernando, M. J. Brown, and E. R. Pardyjak, 2014: On flows in simulated urban canopies. Environ. Fluid Mech., 15, 275-303, doi:10.1007/s10652-013-9311-6. 